\title{
Optical, physical and chemical properties of aerosols transported to a coastal site in the western Mediterranean: a focus on primary marine aerosols
}

\author{
Marine Claeys $^{1}$, Greg Roberts ${ }^{1,2}$, Marc Mallet $^{1}$, Jovanna Arndt ${ }^{3}$, Karine Sellegri ${ }^{4}$, Jean Sciare ${ }^{5,6}$, John Wenger ${ }^{3}$, and \\ Bastien Sauvage $^{7}$ \\ ${ }^{1}$ CNRM, Centre National de Recherches Météorologiques UMR3589, Météo-France/CNRS, Toulouse, France \\ ${ }^{2}$ Scripps Institution of Oceanography, Center for Atmospheric Sciences and Physical Oceanography, La Jolla, USA \\ ${ }^{3}$ Department of Chemistry and Environmental Research Institute, University College Cork, Cork, Ireland \\ ${ }^{4}$ LaMP, Laboratoire de Météorologie Physique CNRS UMR6016, Observatoire de Physique du Globe de Clermont-Ferrand, \\ Université Blaise Pascal, Aubière, France \\ ${ }^{5}$ LSCE, Laboratoire des Sciences du Climat et de l'Environnement, Unité Mixte CEA-CNRS-UVSQ, CEA/Orme des \\ Merisiers, 91191 Gif-sur-Yvette, France \\ ${ }^{6}$ Energy Environement Water Research Center, The Cyprus Institute, 2121 Nicosia, Cyprus \\ ${ }^{7}$ LA, Laboratoire d'Aérologie, Observatoire Midi-Pyrénées, CNRS/IRD/Université de Toulouse, 14, Avenue Édouard Belin, \\ 31400 Toulouse, France
}

Correspondence to: Marine Claeys (marine.claeys@umr-cnrm.fr)

Received: 8 July 2016 - Discussion started: 3 August 2016

Revised: 12 April 2017 - Accepted: 27 April 2017 - Published: 30 June 2017

\begin{abstract}
As part of the ChArMEx-ADRIMED campaign (summer 2013), ground-based in situ observations were conducted at the Ersa site (northern tip of Corsica; $533 \mathrm{~m}$ a.s.1.) to characterise the optical, physical and chemical properties of aerosols. During the observation period, a major influence of primary marine aerosols was detected (22-26 June), with a mass concentration reaching up to $6.5 \mu \mathrm{g} \mathrm{m}^{-3}$ and representing more than $40 \%$ of the total $\mathrm{PM}_{10}$ mass concentration. Its relatively low ratio of chloride to sodium (average of 0.57) indicates a fairly aged sea salt aerosol at Ersa. In this work, an original data set, obtained from online real-time instruments (ATOFMS, PILS-IC) has been used to characterise the ageing of primary marine aerosols (PMAs). During this PMA period, the mixing of fresh and aged PMAs was found to originate from both local and regional (Gulf of Lion) emissions, according to local wind measurements and FLEXPART back trajectories. Two different aerosol regimes have been identified: a dust outbreak (dust) originating from Algeria/Tunisia, and a pollution period with aerosols originating from eastern Europe, which includes anthropogenic and biomass burning sources (BBP). The optical, physical and chemical properties of the observed aerosols, as well as
\end{abstract}

their local shortwave (SW) direct radiative effect (DRE) in clear-sky conditions, are compared for these three periods in order to assess the importance of the direct radiative impact of PMAs compared to other sources above the western Mediterranean Basin.

As expected, AERONET retrievals indicate a relatively low local SW DRF during the PMA period with mean values of $-11 \pm 4$ at the surface and $-8 \pm 3 \mathrm{~W} \mathrm{~m}^{-2}$ at the top of the atmosphere (TOA). In comparison, our results indicate that the dust outbreak observed at our site during the campaign, although of moderate intensity (AOD of $0.3-0.4$ at $440 \mathrm{~nm}$ and column-integrated SSA of 0.90-0.95), induced a local instantaneous SW DRF that is nearly 3 times the effect calculated during the PMA period, with maximum values up to $-40 \mathrm{~W} \mathrm{~m}^{-2}$ at the surface. A similar range of values were found for the BBP period to those during the dust period (SW $\mathrm{DRF}$ at the surface and TOA of $-23 \pm 6$ and $-15 \pm 4 \mathrm{~W} \mathrm{~m}^{-2}$ respectively).

The multiple sources of measurements at Ersa allowed the detection of a PMA-dominant period and their characterisation in terms of ageing, origin, transport, optical and physical properties and direct climatic impact. 


\section{Introduction}

The Mediterranean Basin is a crossroad for air masses bringing different types of aerosols, both from natural and anthropogenic origins (Lelieveld et al., 2012). Of these aerosols, primary marine aerosols (PMAs; mainly composed of sea salt and to a lesser extent of organic matter) are important because they are always present over the Mediterranean Basin and compose the main part of background aerosols over the Mediterranean (Pace et al., 2006). They are able to chemically react with other aerosol species, act as cloud condensation nuclei $(\mathrm{CCN})$ and also interact with solar and thermal radiations due to their large size range (Kaufman et al., 2001; Kaufman and Koren, 2006; Khain, 2009; Li et al., 2011; Seiki and Nakajima, 2014). At the global scale, Bellouin et al. (2008) estimated that the contribution of marine aerosols was equivalent to half of the total direct radiative forcing (DRF), while Zhao et al. (2011) found a contribution of one-third of the total DRF. However, their contribution is highly variable in time and space due to spatial variations in wind speed and long-range transport of marine aerosols. At the regional scale and over the Mediterranean Basin, Salameh et al. (2007) indicate that the contribution of sea salt particles to the total aerosol loading and optical depth ranges from 1 to $10 \%$. They report aerosol optical depth (AOD) around $0.15-0.20$ (at $865 \mathrm{~nm}$ ) within the sea salt aerosol plume during strong-wind (e.g. Mistral and Tramontane) events. In addition, Mulcahy et al. (2008) reported a high correlation between AOD (at $500 \mathrm{~nm}$ ) and wind speed, with AOD values of 0.3-0.4 at moderately high wind speed - most likely related to the increase in PMA. Consequently, the persistent and punctually elevated AOD due to PMAs can have a significant impact on the radiative budget of the Mediterranean Basin. This high variability in terms of PMA loading and optical, physical and chemical properties leads to significant uncertainties in the quantification of regional radiative impact, both for direct and indirect effects (Forster et al., 2007; Stevens and Feingold, 2009). Finally, it should be noted that most past studies have documented aerosol properties in the eastern part of the Mediterranean Basin (Crete Mihalopoulos et al., 1997; Bardouki et al., 2003; Sciare et al., 2003; Koulouri et al., 2008; Greece Chabas and Lefèvre, 2000), even though many studies also took place in the central (Meloni et al., 2004; Di Iorio et al., 2009) and western (Sellegri et al., 2001; Cros et al., 2004; Pey et al., 2009; Guerrero-Rascado et al., 2009) Mediterranean Basin.

In that context, the aim of this study is to characterise the optical, physical and chemical properties of PMAs compared to the other major aerosol sources affecting the western Mediterranean Basin.

This work has taken place in the frame of the ChArMExADRIMED (Chemistry-Aerosols Mediterranean Experiment - Aerosol Direct Radiative Impact on the regional climate in the MEDiterranean region) project (https://charmex.lsce. ipsl.fr) which took place in the western Mediterranean Basin during summer 2013 (Mallet et al., 2016), and we used the real-time measurements taken at the remote ground-based Ersa atmospheric station situated at Cap Corse $\left(42.9694^{\circ} \mathrm{N}\right.$, $9.3803^{\circ} \mathrm{W}$, altitude of $533 \mathrm{~m}$ a.s.1.).

The first section of this paper (Sect. 2) describes the instrumentation deployed at the Ersa station and the FLEXible PARTicle (FLEXPART) model configuration used to identify air mass origins at the station. Periods of the field campaign affected by the major aerosol sources are then discussed (Sect. 3.1 and 3.3) using chemical and physical measurements, as well as back-trajectory analysis and direct radiative effects. Finally, meteorological observations recorded near the sample site (Ersa) during a period characterised by a particularly strong source of PMA is used to address the dependence of PMA mass concentration and ageing to local and regional wind speed (Sect. 3.2.2).

\section{Method}

\subsection{Atmospheric station and instrumental set-up}

The research atmospheric station of Ersa is located at the northernmost part of Corsica (Cap Corse; $42.9694^{\circ} \mathrm{N}$, $9.3803^{\circ} \mathrm{W}$ ). Its altitude is $533 \mathrm{~m}$ above sea level (a.s.l.), and it is surrounded by the Mediterranean sea on its northern, eastern and western sides and by mountains ( $\simeq 1000 \mathrm{~m}$ a.s.l.) on its southern side. The station is located in a remote area, with minimal influence of local anthropogenic emissions. A more detailed description of the station is given by Mallet et al. (2016).

This station is equipped to provide in situ measurement of the aerosol physical properties, including number concentration and number size distribution, using a Scanning Mobility Particle Sizer (SMPS 3081, TSI INC.), an Optical Particle Sizer (OPS 3330, TSI INC.) and an Aerodynamic Particle Sizer (APS 3321, TSI INC.) to characterise both submicron and supermicron aerosol particles. Aerosol size distributions was achieved using two sampling inlets. The first one was a $\mathrm{PM}_{10}$ head inlet, in which the airflow was dried using a Nafion dryer (TSI INC.) to a relative humidity below $40 \%$ and then divided into several paths to the OPS, SMPS and a condensation particle counter (CPC 3010, TSI INC.). The second head inlet was a $\mathrm{PM}_{20}$ with a flow rate of $1 \mathrm{~L} \mathrm{~min}^{-1}$ that sampled for the APS. The flow rate reaching the other instruments was $1 \mathrm{~L} \mathrm{~min}^{-1}$ for the OPS and $0.5 \mathrm{~L} \mathrm{~min}^{-1}$ for the SMPS. The CPC measured the total number aerosol concentration for electric mobility diameters larger than $10 \mathrm{~nm}$. The SMPS counted the number of particles per size bins from 10 to $500 \mathrm{~nm}$, while the APS measured the number of particles per size bins from 0.5 to $20 \mu \mathrm{m}$ and the OPS from 0.3 to $10 \mu \mathrm{m}$ at ambient RH.

Optical corrections to the OPS size distributions are negligible when accounting for the refractive indices associated 
with the different particle types. We considered the particles as spherical (shape factor equal to 1 ).

Particulate matter below 1 and $10 \mu \mathrm{m}\left(\mathrm{PM}_{1}\right.$ and $\left.\mathrm{PM}_{10}\right)$ were measured at the station on an hourly basis using a TEOM-FDMS (Thermo Environment, model 1405-F) and a TEOM (Thermo Environment, model1400) respectively.

Aerosol optical instruments were also deployed (nephelometer TSI INC. at three wavelengths, MAAP) to determine light scattering and absorption properties of aerosols. The nephelometer measured the scattered and backscattered coefficients at three wavelengths, 450 (blue), 550 (green) and $700 \mathrm{~nm}$ (red) with a $\mathrm{PM}_{10}$ head inlet (flow rate of $40 \mathrm{~L} \mathrm{~min}^{-1}$ ), while the MAAP instrument (Multi Angle Absorption Photometer, Thermo Scientific) measured the concentration of $\mathrm{PM}_{2.5}$ black carbon from the absorption of particles at the $670 \mathrm{~nm}$ wavelength. The nephelometer provides the scattering coefficient (not directly linked to the concentration of particles), associated with an indication of the size of aerosols through the spectral dependence of the scattering coefficient between two wavelengths. The nephelometer data are corrected for truncation according to the Anderson and Ogren (1998) method for the total aerosol population. Correction factors of 1.29, 1.29 and 1.26 are applied to the scattering coefficients at the wavelengths 450,550 and $700 \mathrm{~nm}$ respectively.

The PILS-IC measurements were taken using a Particle Into Liquid Sampler (PILS, Orsini et al., 2003) running at $16.8( \pm 0.5)$ LPM and coupled with two ion chromatographs (IC) for the determination of the major cations and anions. More details on this instrumentation and its comparability with other real-time aerosol analysers can be found in Zorn et al. (2008); Sciare et al. (2011); Healy et al. (2013); Crippa et al. (2013); Bressi et al. (2013). Basic and acidic annular denuders (3-channel, URG Corp., USA) were mounted upstream of the PILS instrument and downstream of a PM10 inlet having a $50 \%$ cut-off diameter of $10 \mu \mathrm{m}$ at $16.67 \mathrm{LPM}$. Ambient concentrations of ions were corrected from blanks performed every day for $1 \mathrm{~h}$ and achieved by placing a total filter upstream of the sampling system. Liquid flow rates of the PILS were delivered by peristaltic pumps and set to $1.5 \mathrm{~mL} \mathrm{~min}^{-1}$ for producing steam inside the PILS and 0.37 $( \pm 0.02) \mathrm{mL} \mathrm{min}^{-1}$ for rinsing the impactor. Cation measurements were taken using an IC (Dionex, model ICS1100) equipped with a $2 \mathrm{~mm}$-diameter AutoSuppression, Cation Self-Regenerating Suppressor (CSRS), a 2 mm-diameter CS12 pre-column and column, and a $100 \mu \mathrm{L}$ injection loop. Analyses were performed in isocratic mode at $20 \mathrm{mM}$ of methanesulfonic acid (MSA) at a flow rate of $0.25 \mathrm{~mL} \mathrm{~min}^{-1}$, for the quantitative determination of the five major cations $\left(\mathrm{Na}^{+}, \mathrm{NH}_{4}^{+}, \mathrm{K}^{+}, \mathrm{Mg}^{2+}, \mathrm{Ca}^{2+}\right)$ every $12 \mathrm{~min}$. Based on these IC settings, the detection limit $(2 \sigma)$ for cations was typically $0.1 \mathrm{ppb}$, which corresponds to an atmospheric concentration of $\sim 1 \mathrm{ng} \mathrm{m}^{-3}$. Calibration was performed every 2 weeks for concentrations ranging from 10 to $800 \mathrm{ppb}$ and showed a drift below $5 \%$ for each cation between the begin- ning and the end of the campaign. Anion measurements were taken using an IC (Dionex, model ICS2000) equipped with a $2 \mathrm{~mm}$-diameter Auto-Suppression, Anion Self-Regenerating Suppressor (ASRS), a $2 \mathrm{~mm}$-diameter AS-11 HC pre-column and column, and a $500 \mu \mathrm{L}$ injection loop. Analyses were performed in isocratic mode at $10 \mathrm{mM}$ of $\mathrm{KOH}$ at a flow rate of $0.25 \mathrm{~mL} \mathrm{~min}^{-1}$, for the quantitative determination of the 5 anions (methanesulfonate, $\mathrm{Cl}^{-}, \mathrm{NO}_{3}^{-}, \mathrm{SO}_{4}^{2-}$, oxalate) every $24 \mathrm{~min}$. Based on these IC settings, the detection limit $(2 \sigma)$ for anions was typically $0.1 \mathrm{ppb}$, which corresponds to an atmospheric concentration of $\sim 1 \mathrm{ng} \mathrm{m}^{-3}$. Calibration was performed every 2 weeks for concentrations ranging from 10 to $800 \mathrm{ppb}$ and showed a drift below $5 \%$ for each anion between the beginning and the end of the campaign. To our best knowledge, this is the first time that PILS-IC measurements are reported in $\mathrm{PM}_{10}$, providing a unique opportunity to document water-soluble supermicron ions and sea salt in particular. Quality control of the PILC-IC data was successfully performed by comparison with $\mathrm{PM}_{10}$ filter (Teflon)-based ion measurements taken in parallel on a $12 \mathrm{~h}$ time basis (Leckel, SEQ47/50 model running at $2.3 \mathrm{~m}^{3} \mathrm{~h}^{-1}$ ), with discrepancies typically less than $20 \%$ for the major anions/cations.

PMA concentration was calculated using these data and the following formula (Brewer, 1975):

$$
\begin{aligned}
{[\mathrm{PMA}] } & =\left[\mathrm{Cl}^{-}\right]+\left[\mathrm{Na}^{+}\right]+\left[\mathrm{ss}-\mathrm{Mg}^{2+}\right]+\left[\mathrm{ss}-\mathrm{SO}_{4}^{2-}\right] \\
& +\left[\mathrm{ss}-\mathrm{Ca}^{2+}\right]+\left[\mathrm{ss}-\mathrm{K}^{+}\right],
\end{aligned}
$$

where $[\mathrm{ss}-\mathrm{X}] /\left[\mathrm{Na}^{+}\right]=0.13,0.251,0.039$ and 0.036 corresponding to $\mathrm{Mg}^{2+}, \mathrm{SO}_{4}^{2-}, \mathrm{Ca}^{2+}$ and $\mathrm{K}^{+}$respectively. The ACSM measured the chemical composition of non-refractory $\mathrm{PM}_{1}$, including organic matter $(\mathrm{OM})$, nitrate $\left(\mathrm{NO}_{3}\right)$, sulfate $\left(\mathrm{SO}_{4}\right)$, ammonium $\left(\mathrm{NH}_{4}\right)$, chloride $(\mathrm{Cl})$, with a time resolution of $30 \mathrm{~min}$. The chemical composition of non-refractory submicron aerosol has been continuously monitored using a Quadrupole Aerosol Chemical Speciation Monitor (Aerodyne Research Inc.), which has been described in detail by $\mathrm{Ng}$ et al. (2011). Briefly, $\mathrm{PM}_{2.5}$ aerosols are sampled at $3 \mathrm{~L} \mathrm{~min}^{-1}$ (from a $\mathrm{PM}_{2.5}$ cyclone inlet) and then subsampled at $85 \mathrm{~mL} \mathrm{~min}^{-1}$ (volumetric flow) through an aerodynamic lens, focusing submicron particles $(40-1000 \mathrm{~nm}$ aerodynamic diameter, $\mathrm{AD}$ ) onto a $600 \mathrm{C}$-heated conical tungsten vaporiser where non-refractory material is flash vaporised and quasi-instantaneously ionised by electron impact at $70 \mathrm{eV}$. Briefly, the instrument calibration has been performed following the recommendation of Jayne et al. (2000) and $\mathrm{Ng}$ et al. (2011), where generated monodisperse $300 \mathrm{~nm}$ A.D. ammonium nitrate particles are injected into both ACSM and a CPC at different concentrations. It has been successfully compared with 15 other aerosol mass spectrometers (Crenn et al., 2015; Fröhlich et al., 2015). Quality control of ACSM data was successfully performed by comparison of $\mathrm{PM}_{1}$ (sum of chemical species measured by ACSM and MAAP; considering that $\mathrm{BC}$ aerosols are mainly $\mathrm{PM}_{1}$ ) with $\mathrm{PM}_{1}$ obtained with SMPS (with density of 1.5 ). 
The ATOFMS (aerosol time-of-flight mass spectrometer), deployed by University College Cork, measured the vacuum aerodynamic diameter of the individual particles and their chemical composition. A detailed description of the ATOFMS (TSI INC. model 3800) can be found elsewhere (Gard et al., 1997). Briefly, it consists of an aerodynamic focusing lens (TSI AFL100; Su et al., 2004) that transmits particles in the diameter range $100-3000 \mathrm{~nm}$, a particle sizing region, and a bipolar reflection time-of-flight mass spectrometer. Single particles are desorbed/ionised using a pulsed Nd:YAG laser $\left(\lambda=266 \mathrm{~nm}, \simeq 1 \mathrm{~mJ}\right.$ pulse $\left.^{-1}\right)$. Positive and negative ion mass spectra of individual aerosol particles are obtained which enable identification of the chemical constituents. The AFL reduces the transmission efficiency of supermicron particles, while variability in the desorption/ionisation laser influence results in qualitative mass spectral signals.

The aerosol optical properties were retrieved from the AERONET/PHOTONS network. We used here the level 1.5 data obtained from the sun-photometer located near Ersa station (http://aeronet.gsfc.nasa.gov/cgi-bin/type_one_station_ opera_v2_new); the AOD derived at eight wavelengths (from 340 to $1640 \mathrm{~nm}$ ), the Ångström exponent (AE) was calculated using the AOD at 440 and $870 \mathrm{~nm}$, and the volume size distribution was retrieved from the algorithm proposed by Dubovik et al. (2002b). The single scattering albedo (SSA) provides crucial information related to the ratio of scattering to extinction (scattering plus absorbing) of radiations by aerosols. The sun photometer data are available several times per day, depending on the solar angle and aerosol loading (Dubovik et al., 2002b). We have also used the aerosol clear-sky instantaneous direct radiative effect in the shortwave derived from sun-photometer measurements, following the methodology proposed by García et al. (2012). The accuracy of the AERONET retrievals are discussed by Dubovik and King (2000) and Dubovik et al. (2002a).

Temperature, relative humidity, wind speed and direction measured in real-time over the whole campaign were taken from the Ersa atmospheric station. Because the wind measurements may have been influenced by the orography around the station, we used the wind data provided by the closest Météo-France station (Semaphore station), which was situated about $5 \mathrm{~km}$ away from Ersa and close to the sea. When the study mentions local wind measurements, it refers to wind observed at the Semaphore station.

\subsection{ATOFMS data analysis}

The distinction between aged and fresh sea salt was made according to the detection of chloride and nitrate in the particles. For fresh sea salt, we obtained signals for various chloride ions $\left({ }^{81,83} \mathrm{Na}_{2} \mathrm{Cl}^{+},{ }^{35,37} \mathrm{Cl}^{-}\right.$and $\left.{ }^{93,95} \mathrm{NaCl}_{2}^{-}\right)$and also some nitrate $\left({ }^{46} \mathrm{NO}_{2}^{-},{ }^{62} \mathrm{NO}_{3}^{-}\right)$. The signals for chloride are generally lower for aged sea salt and those for nitrate are stronger due to the replacement of chloride and sodium ni- trate formation (Noble and Prather, 1997; Gard et al., 1998). In this case, the relatively small signals for chloride ions is a good indicator of aged sea salt aerosol. The size distribution of aged and fresh sea salts was investigated using this differentiation. Regarding the size distribution, the main limitation is the upper cut-off size of $3 \mu \mathrm{m}$ which limits the detection mostly to fine sea salt particles.

Average mass spectra for aged and fresh are shown in Fig. 1. Both sea salt classes are typical of those observed in other coastal/marine environments (Gard et al., 1998; Dall'Osto et al., 2004; Healy et al., 2010). The positive modes for both fresh and aged particles are similar and are characterised by sodium ions $\left({ }^{23} \mathrm{Na}^{+},{ }^{46} \mathrm{Na}_{2}^{+},{ }^{62} \mathrm{Na}_{2} \mathrm{O}^{+}\right.$, ${ }^{63} \mathrm{Na}_{2} \mathrm{OH}^{+}$and $\left.{ }^{81,83} \mathrm{Na}_{2} \mathrm{Cl}^{+}\right)$and ${ }^{39} \mathrm{~K}^{+}$. The negative mass spectra for fresh sea salt particles shows peaks for ${ }^{16} \mathrm{O}^{-}$, ${ }^{35,37} \mathrm{Cl}^{-}$, nitrate $\left({ }^{46} \mathrm{NO}_{2}^{-},{ }^{62} \mathrm{NO}_{3}^{-}\right)$and ${ }^{93,95} \mathrm{NaCl}_{2}^{-}$, while the signals for nitrate dominate the aged sea salt negative mode and sodium chloride adducts are virtually absent. The occurrence and relative intensity of the chloride and $\mathrm{NaCl}$ adducts in ATOFMS mass spectra are key markers for distinguishing fresh sea salt from aged sea salt. The absence of $\mathrm{NaCl}$ ions and strong nitrate signals indicates extensive replacement of $\mathrm{Cl}$ by $\mathrm{NO}_{3}$, while the presence of nitrate in the negative mass spectra of the fresh sea salt particles suggests that these are not truly fresh but have also undergone some $\mathrm{Cl}$ replacement.

\subsection{FLEXPART model}

We used the FLEXPART Lagrangian dispersion model (Stohl et al., 1998), version 9.02. FLEXPART in a backward mode during the campaign to identify the sources and the transport time of air masses observed at the Ersa station. The model is driven by wind fields provided by the European Centre for Medium-Range Weather Forecast (ECMWF) using both analyses and forecasts with a temporal resolution of $3 \mathrm{~h}(00: 00,06: 00,12: 00,18: 00 \mathrm{~h}$ UTC for analyses and 03:00, 09:00, 15:00, 21:00 $\mathrm{h}$ UTC for forecast). The horizontal resolution is $0.141^{\circ} \times 0.141^{\circ}$ and 91 vertical levels are used (137 after 25 June 2013). Turbulence is parameterised solving Langevin equations (Stohl and Thomson, 1999) and the convection parameterisation scheme is adopted from Emanuel and Živkovic-Rothman (1999) for all types of convection. The model calculates trajectories of user-defined ensembles of particles released from a threedimensional box in backward mode over 6 days. In this study $10^{4}$ particles were released at the beginning of each run in a $100 \mathrm{~km} \times 160 \mathrm{~km} \times 200 \mathrm{~m}$ (lat $\times$ lon $\times$ alt) box centred above Cap Corse (northern tip of Corsica). Back trajectories were modelled for three different altitudes: $500 \mathrm{~m}$ (bottom and top of the box at 400 and $600 \mathrm{~m}$ respectively), corresponding to the altitude of the measurement site at Ersa; $2000 \mathrm{~m}$, corresponding to an altitude above the boundary layer; and $4000 \mathrm{~m}$, corresponding to an altitude where the ATR 42 research aircraft mainly observed dust plumes (Mallet et al., 2016). Besides the particles' positions, FLEXPART 


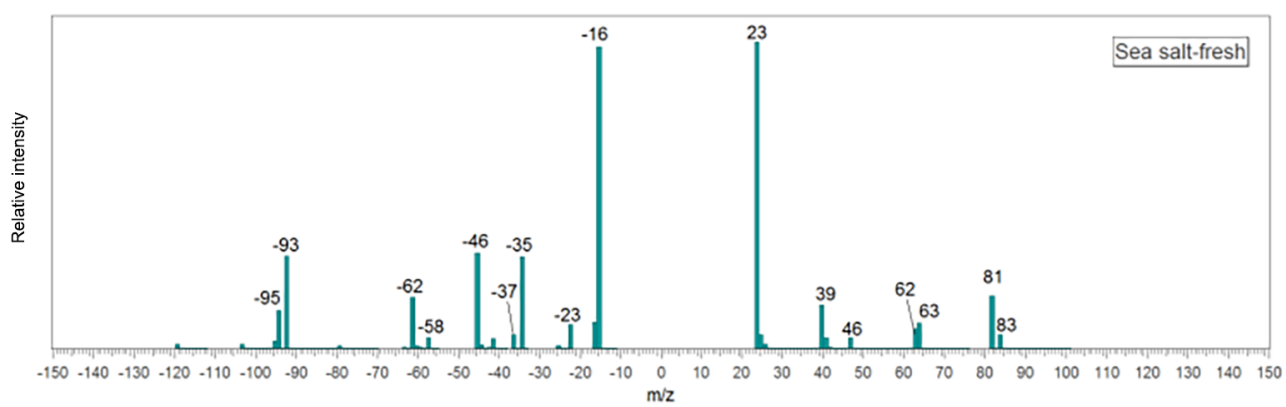

\begin{tabular}{|c|c|}
\hline \multicolumn{2}{|c|}{ Positive ions } \\
\hline 23 & $\mathrm{Na}^{+}$ \\
\hline 39 & $\mathrm{~K}^{+}$ \\
\hline 46 & $\mathrm{Na}_{2}^{+}$ \\
\hline 62,63 & $\mathrm{Na}_{2} \mathrm{O}^{+}, \mathrm{Na}_{2} \mathrm{OH}^{+}$ \\
\hline 81,83 & $\mathrm{Na}_{2} \mathrm{Cl}^{+}$ \\
\hline \multicolumn{2}{|c|}{ Negative ions } \\
\hline-16 & $\mathrm{O}^{-}$ \\
\hline-23 & $\mathrm{Na}^{+}$ \\
\hline-26 & $\mathrm{CN}^{-}$ \\
\hline-42 & $\mathrm{CNO}$ \\
\hline-35 & $\mathrm{Cl}^{\circ}$ \\
\hline-46 & $\mathrm{NO}_{2}^{-}$ \\
\hline-62 & $\mathrm{NO}_{3}^{-}$ \\
\hline-58 & $\mathrm{NaCl}$ \\
\hline$-93,-95$ & $\mathrm{NaCl}_{2}^{-}$ \\
\hline-104 & $\mathrm{NaBr}$ \\
\hline-120 & $\mathrm{KBr}$ \\
\hline
\end{tabular}

Figure 1. Average mass spectra for fresh and aged sea salt particles observed during ADRIMED.

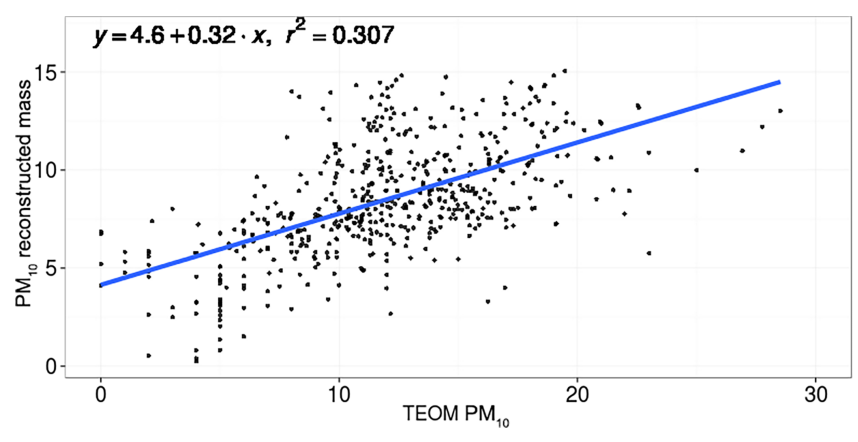

Figure 2. Scatter plot of TEOM $\mathrm{PM}_{10}$ mass concentration as a function of the $\mathrm{PM}_{10}$ reconstructed mass concentration for the ADRIMED period.

also includes cluster analysis for particle ensembles (Stohl et al., 2002) and the average residence time of particles in the output grid cells. Cluster analysis uses the plume dispersion information (residence time) to calculate 10 clusters at each time step ( $3 \mathrm{~h}$ ) (using the k-means clustering), synthesising the particle dispersion information. All the particles are contained and allocated in these 10 clusters according to their position (latitude, longitude and altitude; $Z$ ). The horizontal resolution for the FLEXPART output grid was $1^{\circ} \times 1^{\circ}$ and the vertical resolution was $500 \mathrm{~m}$ from the ground up to $9500 \mathrm{~m}$.

\subsection{Aerosol mass closure}

In order to assess the consistency of the chemical data set, we compared the TEOM $\mathrm{PM}_{10}$ and $\mathrm{PM}_{1}$ data with the on- line chemical concentration measurements taken in parallel. $\mathrm{PM}_{10}$ mass concentrations were compared to the sum of chemical components obtained from the PILS-IC PM PM $_{10}$ data, the BC concentration from the MAAP instrument $\left(\mathrm{PM}_{2.5}\right)$, and the organic matter $(\mathrm{OM})$ concentration derived from the ACSM instrument $\left(\mathrm{PM}_{1}\right)$.

The ratio of the reconstructed mass over the TEOM PM10 mass concentration averaged 0.79 during the ADRIMED campaign. It is lower during the PMA period $(0.65 \pm 0.20)$ compared to the BBP period $(0.74 \pm 0.23)$. We did not measure TEOM PM10 during the dust period. We did not find any significant correlation between missing mass and TEOM PM10 mass, even though the missing mass is globally higher when the PM10 total mass is higher. This lack of aerosol mass could also be due to the mass of (insoluble) dust not determined chemically or possibly a supermicron mode of organic that was not determined here. Indeed, the organic mass fraction can represent more than $10 \%$ of the sea spray mass for aerosols between 1 and $3 \mu \mathrm{m}$ during a period of high biological activity (Gantt and Meskhidze, 2013). This ratio decreases with increasing size. Even though full mass closure has not been reached, there is no impact on the results because the losses do not represent sources by themselves. The three main aerosol types presented in this paper have been determined using key chemical tracers (measured by the PILS and ACSM), optical properties (MAAP and nephelometer), FLEXPART back-trajectory analysis for confirmation. The combination of these different analyses conducted in this study is found to be coherent and representative of the whole aerosol population. 


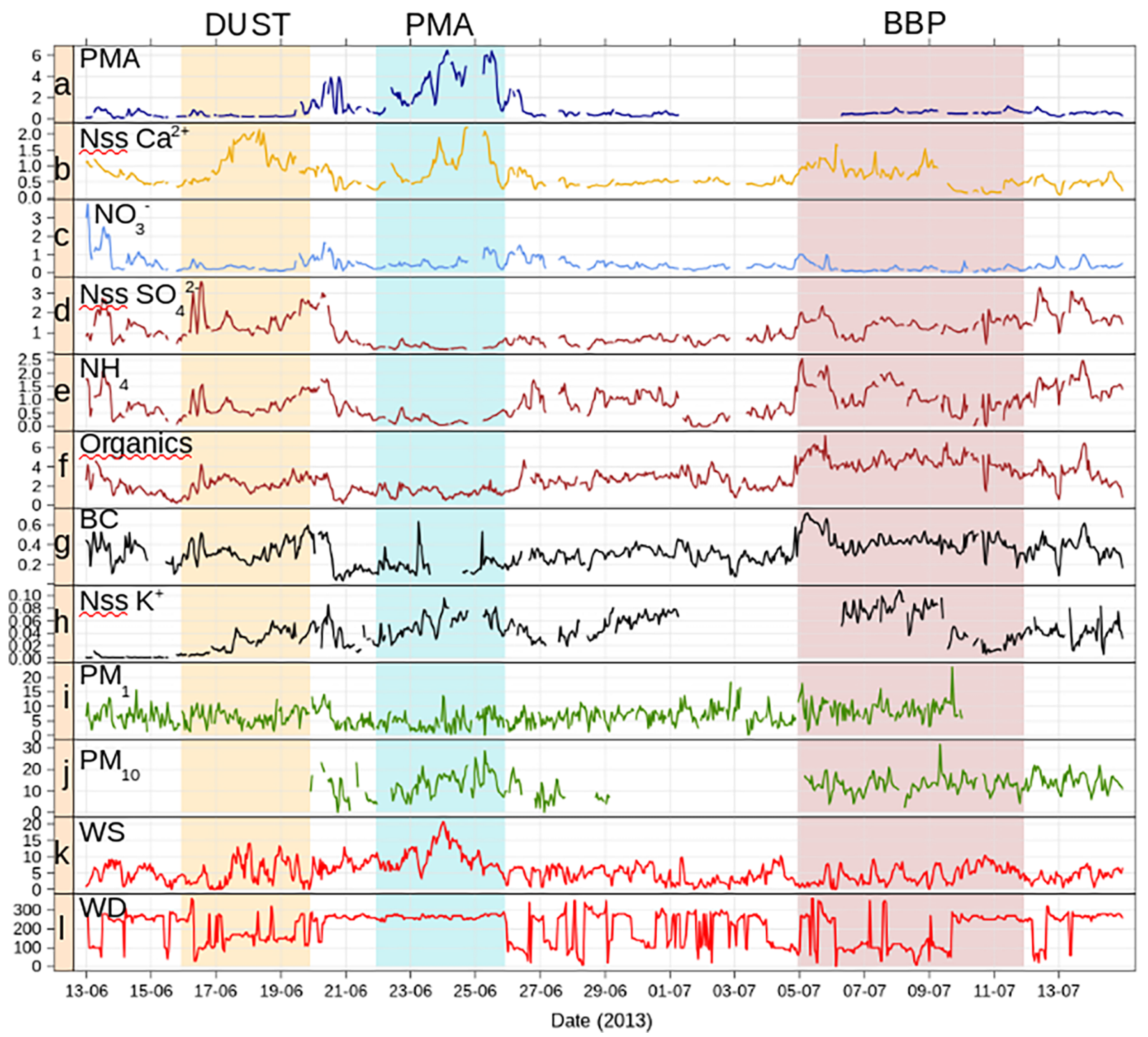

Figure 3. Time series of chemical species $\left(\mathrm{in} \mu \mathrm{g} \mathrm{m}^{-3}\right)$, wind speed $\left(\mathrm{m} \mathrm{s}^{-1}\right)$ and direction $\left({ }^{\circ}\right)$ : (a) PMA mass concentration calculated from PILS-IC measurements, (b) nss-Ca ${ }^{2+}$ mass concentration measured by PILS-IC measurements, (c) nss- $\mathrm{NO}_{3}^{-}$mass concentration measured by the PILS-IC, (d) nss-SO ${ }_{4}^{2-}$ mass concentration measured by the PILS-IC, (e) nss- $\mathrm{NH}_{4}^{+}$mass concentration measured by the PILS-IC, (f) organic mass concentration measured by the ACSM, (g) black carbon mass concentration measured by the MAAP, (h) nss-K ${ }^{+}$mass concentration measured by the PILS-IC, (i) $\mathrm{PM}_{1}$ mass concentration measured by TEOM PM 1 , (j) $\mathrm{PM}_{10}$ mass concentration measured by TEOM PM 10 , (k) wind speed measured at the Semaphore, (l) wind direction measured at the Semaphore. The shaded areas correspond to the three identified periods: orange for dust, blue for primary marine aerosols (PMAs) and brown for biomass burning/pollution (BBP).

For this study, the sulfate $\left(\mathrm{SO}_{4}^{2-}\right)$ and $\mathrm{NH}_{4}^{+}$data were taken from the PILS-IC instrument as the correlation between ACSM and PILS-IC measurements show a very good agreement $\left(\mathrm{SO}_{4}^{2-}(\mathrm{PILS})=0.99 \times \mathrm{SO}_{4}^{2-}(\mathrm{ACSM})\right), r^{2}=0.95$ and $\left.\mathrm{NH}_{4}^{+}(\mathrm{PILS})=1.27 \times \mathrm{NH}_{4}^{+}(\mathrm{ACSM}), r^{2}=0.87\right)$.

\section{Results}

\subsection{Overview of aerosols sources}

In this section, the chemical properties of the aerosols measured in Ersa (Fig. 3) are first studied, revealing a significant variability in the contribution of the different aerosol species and outlining three main periods, dust, PMA and BBP, under the influence of different types of air masses and particles. The aerosol physical properties are then discussed in Sect. 3.2.3 and 3.3.1. 


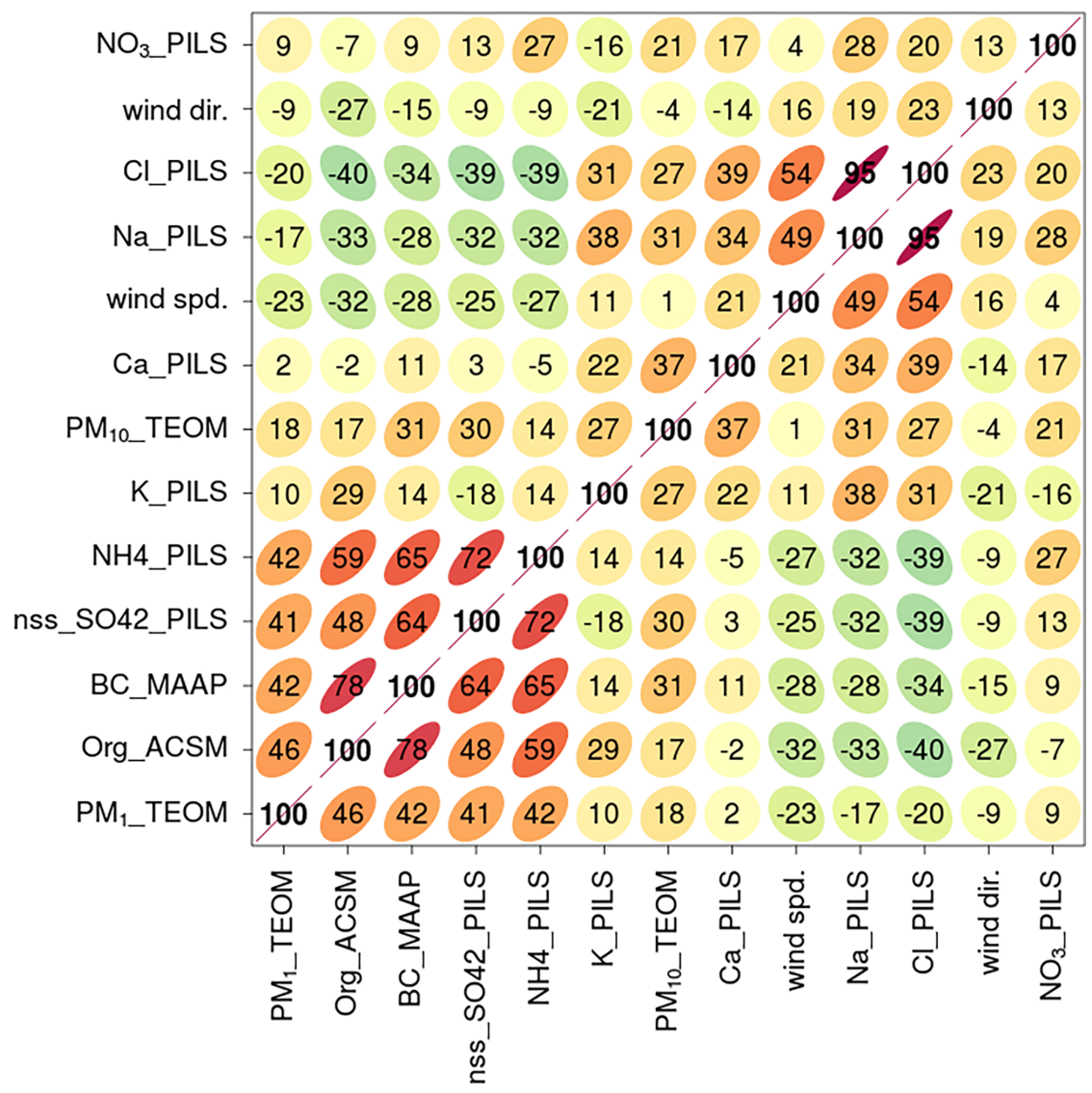

Figure 4. Correlation plot of chemical components mass concentrations, $\mathrm{PM}_{1}$ and $\mathrm{PM}_{10}$ mass concentration and wind speed and direction, over the whole campaign.

The mean $\mathrm{PM}_{10}$ concentration measured by the TEOM $\mathrm{PM}_{10}$ during the ADRIMED campaign was $11.5 \pm 5.4 \mu \mathrm{g} \mathrm{m}^{-3}$. For the majority of the sampling period the mass concentration ranged from 10 to $20 \mu \mathrm{g} \mathrm{m}^{-3}$, except for short periods when the concentration fell to $5 \mu \mathrm{g} \mathrm{m}{ }^{-3}$. These decreases are usually due to wet scavenging or the diurnal variation of the boundary layer, as the Ersa station was within the boundary layer during daytime and sometimes slightly above the boundary layer at night-time (aerosol concentrations at night were often lower when the Ersa site was in the free troposphere). In parallel, the mean $\mathrm{PM}_{1}$ concentration measured by the TEOM $\mathrm{PM}_{1}$ during ADRIMED was $6.4 \pm 3.2 \mu \mathrm{g} \mathrm{m}^{-3}$. The concentration was lower during June and rises during the beginning of July to exceed $10 \mu \mathrm{g} \mathrm{m}^{-3}$. The major chemical constituents of $\mathrm{PM}_{10}$ measured at Ersa (Fig. 3) show a significant temporal variability during the campaign. A correlation plot (Fig. 4) illustrates the relationship between the principal chemical constituents, $\mathrm{PM}_{1}$ and $\mathrm{PM}_{10}$ mass concentrations, as well as wind speed and direction. In the figure, the order of the variables appear due to their similarity with one another, through hierarchical analysis (Carslaw and Ropkins, 2012). The colour and the number represent the correlation between two variables: when close to 100 , the correlation is high The shape of the ellipse is a visual representation of a scatter plot. We can observe two groups of variables on this figure. The first one is composed of $\mathrm{Cl}^{-}, \mathrm{Na}^{+}, \mathrm{Ca}^{2+}$, $\mathrm{K}$ and $\mathrm{PM}_{10}$ mass concentration and related to marine or terrestrial influence, while the second one, composed of $\mathrm{NH}_{4}^{+}, \mathrm{SO}_{4}^{2-}, \mathrm{BC}$, organics and $\mathrm{PM}_{1}$ mass concentration, is related to pollution influence. Three main periods under the influence of different types of air masses and aerosols have been selected here and discussed in more details below.

The first period (16 to 20 June) corresponds to a dust outbreak and is characterised by the concentration of non-seasalt calcium (nss- $\mathrm{Ca}^{2+}$ ) concentration, a proxy of desert dust (Sciare et al., 2003), which increases from 0.5 to $2 \mu \mathrm{g} \mathrm{m}^{-3}$. This dust event lasted a few days, from 16 to 20 June, with nss- $\mathrm{Ca}^{2+}$ concentrations peaking on 18 June at $2 \mu \mathrm{g} \mathrm{m}^{-3}$ at the Ersa site. In addition, the concentrations of calcium measured by the PILS-IC are relatively low for a dust event, because the maximum concentration of dust particles was located at an altitude ranging between 3 and $6 \mathrm{~km}$ (Denjean et al., 2016). The second reason concerns the method used by the PILS-IC instrument, which analyses only the soluble fraction of aerosols, while a significant part of dust $\mathrm{Ca}$ 


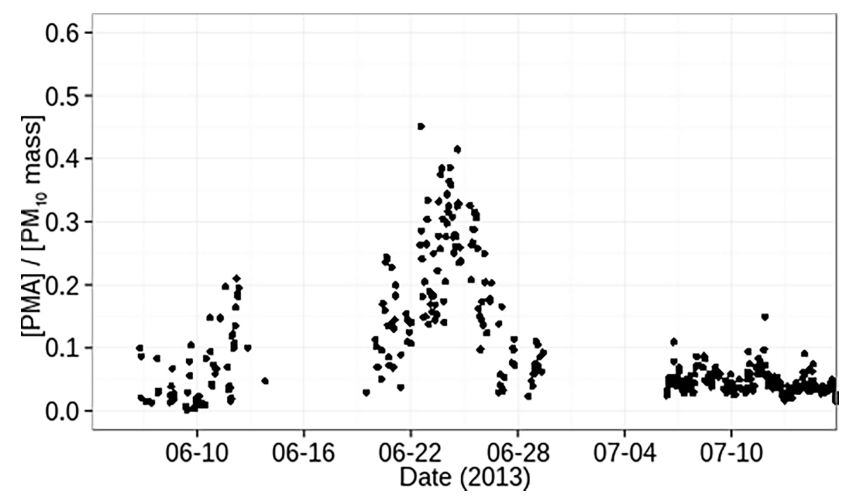

Figure 5. Ratio of inorganic sea salt mass concentration (PILS-IC) over $\mathrm{PM}_{10}$ mass concentration $\left(\mathrm{TEOM} \mathrm{PM}_{10}\right)$.

is insoluble. In that sense, the concentration of nss- $\mathrm{Ca}^{2+}$ determined by PILS-IC remains a qualitative indicator of the presence of dust particles.

PILS-IC measurements also indicate an increase in the concentrations of oxalate, potassium, $\mathrm{SO}_{4}^{2-}$ and $\mathrm{NH}_{4}^{+}$from 5 to 9 July, which correspond to BBP influences. A brief increase of $\mathrm{NO}_{3}^{-}$concentrations (PILS-IC) was recorded on 5 and 6 July (Fig. 3). This event was also detected by the ACSM. Indeed, there is a difference of a factor of 2 in terms of total mass concentrations between the first part of the campaign (6 June to 4 July) and during the BBP period. During the first period (6 June to 4 July), the mass concentration of each aerosol species is low, characterised by a mean total concentration of $3.7 \pm 1.6 \mu \mathrm{g} \mathrm{m}^{-3}$. During the second identified period ( 4 to 13 July), the total $\mathrm{PM}_{1}$ aerosol mass concentration increases suddenly to reach a mean of $7.2 \pm 1.7 \mu \mathrm{g} \mathrm{m}^{-3}$. Similarly, the total PM1 mass concentration measured by the TEOM increases from $5.9 \pm 3.0$ to $8.4 \pm 3.3 \mu \mathrm{g} \mathrm{m}^{-3}$. This increase is mainly due to a large addition of the concentration of submicronic organics compounds (from $2.1 \pm 0.9 \mu \mathrm{g} \mathrm{m}^{-3}$ to $4.1 \pm 1.2 \mu \mathrm{g} \mathrm{m}^{-3}$ ) and an increase of $\mathrm{SO}_{4}^{2-}$ (and $\mathrm{NH}_{4}^{+}$) from $0.9 \pm 0.6(0.5 \pm 0.3)$ to $1.8 \pm 0.6(0.9 \pm 0.3) \mu \mathrm{g} \mathrm{m}^{-3}$. organics, sulfate and ammonium concentrations remain high until $10 \mathrm{July}$, when they decrease, but to values that are still higher than during the month of June. In parallel, the black carbon (BC) concentration is found to be low throughout the whole period of the campaign, although we observe an increase during July (mean of $0.41 \pm 0.11 \mu \mathrm{g} \mathrm{m}^{-3}$ ) compared to June (mean of $0.28 \pm 0.11 \mu \mathrm{g} \mathrm{m}^{-3}$ ). For a few days and during the PMA period, the concentration of $\mathrm{BC}$ is found to be very low $\left(0.20 \pm 0.09 \mu \mathrm{g} \mathrm{m}^{-3}\right)$ and recovers its previous concentration by 3 July. The highest BC concentration $\left(0.75 \mu \mathrm{g} \mathrm{m}^{-3}\right)$ was reached on 5 July. The ACSM observations clearly indicate that concentrations of all the chemical components during the BBP episode are twice the concentration they had during the first period of the ADRIMED campaign. Similar episodes of biomass burning events of European origin were studied by Ripoll et al. (2015) at a Mediterranean site, with an increase in the concentration of $\mathrm{PM}_{10}$ nitrate (6 times higher than the annual average), sulfate (about 3 times higher than the annual average), ammonium (more than 4 times higher than the annual average), OM (about 2 times higher than the annual average) and potassium ( 2 times higher than the annual average).

Our observations reveal that the mean concentration of inorganic PMA (averaged for the months of June and July 2013) was found to be low with a value of $0.76 \pm 1.04 \mu \mathrm{g} \mathrm{m}^{-3}$ (Fig. 3). However, during the PMA period, the concentration of PMA increases up to $6.5 \mu \mathrm{g} \mathrm{m}^{-3}$, with a mean concentration of $3.2 \pm 1.8 \mathrm{\mu g} \mathrm{m}^{-3}$. For this specific period, the mass of PMA represents, on average, $22 \%$ of the total mass measured by the TEOM $\mathrm{PM}_{10}$ instrument, while the average contribution was about $7 \%$ for the whole period of observations. At the Ersa station, the highest concentration of PMA was reached on 24 June, when PMA concentration represented $40 \%$ of hourly $\mathrm{PM}_{10}$ mass concentration for $25 \%$ of the data (Fig. 5). Even though the mean values of PMA mass concentration measured at Ersa were low compared to values referenced at other Mediterranean sites, this contribution still remains significant. Indeed, Pey et al. (2009) reported a ratio of $10 \%$ of sea spray (sum of $\mathrm{Na}$ and $\mathrm{Cl}^{-}$mass concentrations from Quartz fibre filter) to $\mathrm{PM}_{10}$ (annual mean $\left.=2.9 \mu \mathrm{g} \mathrm{m}^{-3}\right)$ in Mallorca $(117 \mathrm{~m}$ a.s.1. $)$, while Bardouki et al. (2003) found a contribution of $40 \%$ of PMA in the coarse mode of inorganic ions during summer at Finokalia (150 m a.s.l., Crete). Querol et al. (2009) analysed the chemical composition of $\mathrm{PM}_{10}$ aerosols in the Mediterranean Basin and found a mean annual contribution of sea spray to $\mathrm{PM}_{10}$ that did not exceed $24 \%$. So the contribution of inorganic sea salt to the $\mathrm{PM}_{10}$ mass concentration in the Mediterranean Basin is on average lower than $20 \%$ but can reach $40 \%$ during particular events such as the one observed at Ersa in June 2013. Moreover, sea spray likely comprises a substantial fraction of organic PMA and hence may represent a larger fraction of $\mathrm{PM}_{10}$ than the one estimated solely from the inorganic fraction (Gantt and Meskhidze, 2013). Furthermore, while the contribution of PMA to $\mathrm{PM}_{10}$ mass concentration is high during the PMA period, the mass contribution of nss ions to the total ionic content is relatively low during the PMA period $(53 \pm 11 \%)$. In comparison, the mass contribution of nss-ions to the total ionic content is $84 \pm 5 \%$ for the ADRIMED field campaign, and is $82 \pm 14$ and $92 \pm 3 \%$ for the dust and BBP periods respectively. Furthermore, the $\mathrm{Ca}^{2+}$ concentration measured during the PMA period (up to $2 \mu \mathrm{g} \mathrm{m}^{-3}$ ) indicates the presence of dust particles, probably related to strong winds lifting soil/dust in the vicinity of the Ersa station (Arndt et al., 2017). However, unlike the dust period, they do not represent the dominant aerosol influence during the PMA period.

However, unlike the dust period (16-20 June), the major aerosol influence during the PMA period is PMA, with a mass concentration reaching $6.5 \mu \mathrm{g} \mathrm{m}^{-3}$, which is 

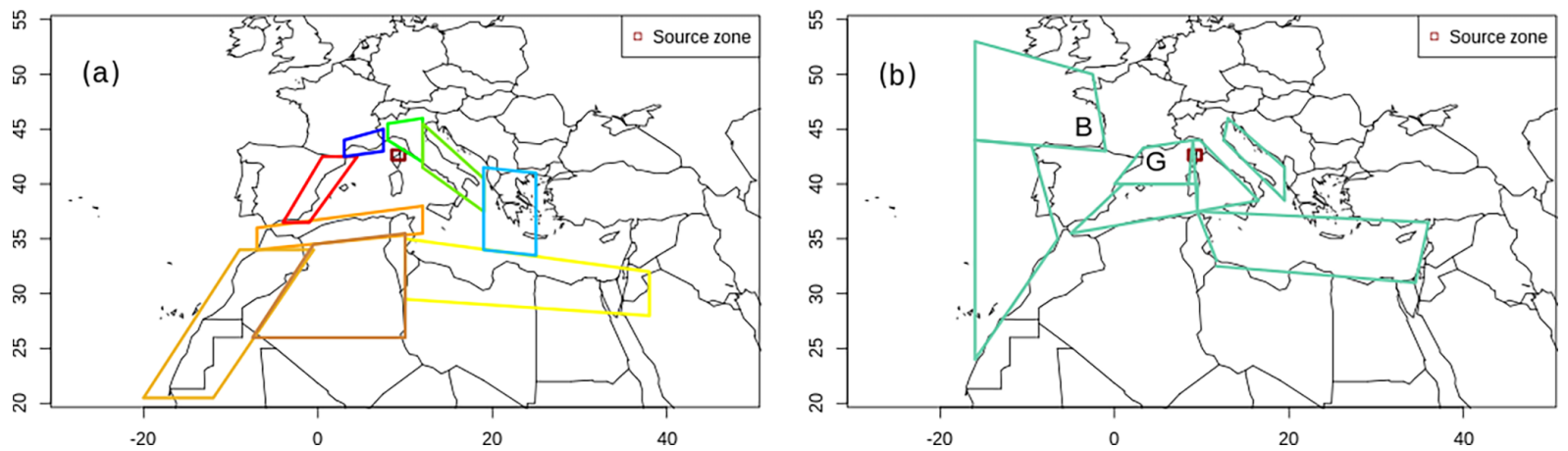

Figure 6. Maps representing the different zones used for the study of the origin of air masses with FLEXPART. (a) Anthropogenic and desert zones (red for Spanish coasts, dark blue for French coasts, green for Italy, blue for Greece, orange and yellow for northern Africa. (b) Marine zones ( $\mathrm{G}$ corresponds to Gulf of Lion, B to Bay of Biscay).

3 times higher than nss- $\mathrm{Ca}^{2+}$ mass concentration. Indeed, during the dust period, PMA mass concentration is low $\left(0.4 \pm 0.3 \mu \mathrm{g} \mathrm{m}^{-3}\right)$ and so the main aerosol mass contribution are dust particles.

\subsubsection{Origins and time of residence of the different air-masses observed at Ersa}

The origin of air masses impacting Ersa for the three different periods depicted in Fig. 3 has been investigated using FLEXPART model in order to characterise the transport time and the emitting sources of these aerosols.

Figure 7a represents the time series computed from clusters of FLEXPART back trajectories. The upper one represents the transport of the air masses passing over different regions before reaching the Ersa station. These different zones take into account the regions influenced by anthropogenic pollution, biomass burning and marine influences and are represented in Fig. 6. They represent the most probable influence on air masses arriving in Cap Corse due to their close locations and specific emissions. For each day during the campaign (bottom axes), the upper figure indicates the different zones through which the air masses passed before reaching Ersa. The bottom figure indicates the transport time from these zones to the Ersa sample site.

In general, the Ersa station was influenced by air masses coming from the west and south during the first part of the field campaign (from 6 to 26 June), and was more influenced by air masses coming from the east and north during the last part of the campaign (26 June to 13 July). During the campaign, Ersa was always affected by air masses that passed over French or Italian coastal areas. The influence of the Mediterranean coasts of Spain is also very present during the campaign, especially in the first part of June.

In terms of transport time, FLEXPART simulations indicate that air masses spent a few hours to several days over the sea after leaving the French or Italian coasts, and 2 to 6 days from continental European sources. Coastal regions are likely the source of anthropogenic-pollution impacted air masses, because they are highly industrialised and populated and are the last major source of anthropogenic aerosols before transport over the Mediterranean Sea. At the local scale, Ersa was mostly under the influence of a westerly wind $\left(\simeq 270^{\circ}\right.$; Fig. 3$)$ from the beginning of the campaign to the beginning of July, expect for a few days during the dust outbreak (from 16 to 20 June), where it was under a south-eastern influence $\left(\simeq 150^{\circ}\right)$. Finally, from 4 to 9 July, Ersa was mostly experiencing an easterly wind $\left(\simeq 100^{\circ}\right)$.

The influence of southerly air masses is marked by the passage of air masses above northern Africa, at the beginning of the campaign (19 June, Fig. 8). The transport time of air masses from northern Africa to Ersa ranges between 2 and 6 days. Such air masses contain significant concentrations of mineral dust particles, which are usually transported at higher altitudes over the Mediterranean Basin, in the free troposphere and up to $9 \mathrm{~km}$ in altitude (Denjean et al., 2016; Hamonou et al., 1999; Dulac and Chazette, 2003; Di Iorio et al., 2009; Mona et al., 2006; Gómez-Amo et al., 2011). Thus, we also performed simulations starting at $4000 \mathrm{~m}$ a.s.l., that show that the air masses arriving at Cap Corse on 19 and 20 June were within the boundary layer $(<1000 \mathrm{~m})$ over Tunisia and Algeria from 2 to 3 days before. At the Ersa site, during the dust outbreak around 19 June, the wind speed reached $15 \mathrm{~m} \mathrm{~s}^{-1}$.

Besides the coastal anthropogenic influence observed during the first week of July, Fig. 8 shows that the air masses came from eastern Europe from 7 to 12 July, and in particular from Ukraine, 3-4 days before reaching Ersa. The date at which the air masses passed over these regions corresponds to significant emissions of biomass burning observed near the Black Sea as shown by the MODIS satellite retrievals (http: //rapidfire.sci.gsfc.nasa.gov/cgi-bin/imagery/firemaps.cgi).

FLEXPART back-trajectory simulations also show that during the PMA period, air masses were coming from the north-west of Cap Corse, including the Gulf of Lion. This is consistent with a higher PMA concentration in Ersa, as a longer fetch leads to higher mass concentration. Our simula- 
(a)

Indication of sources
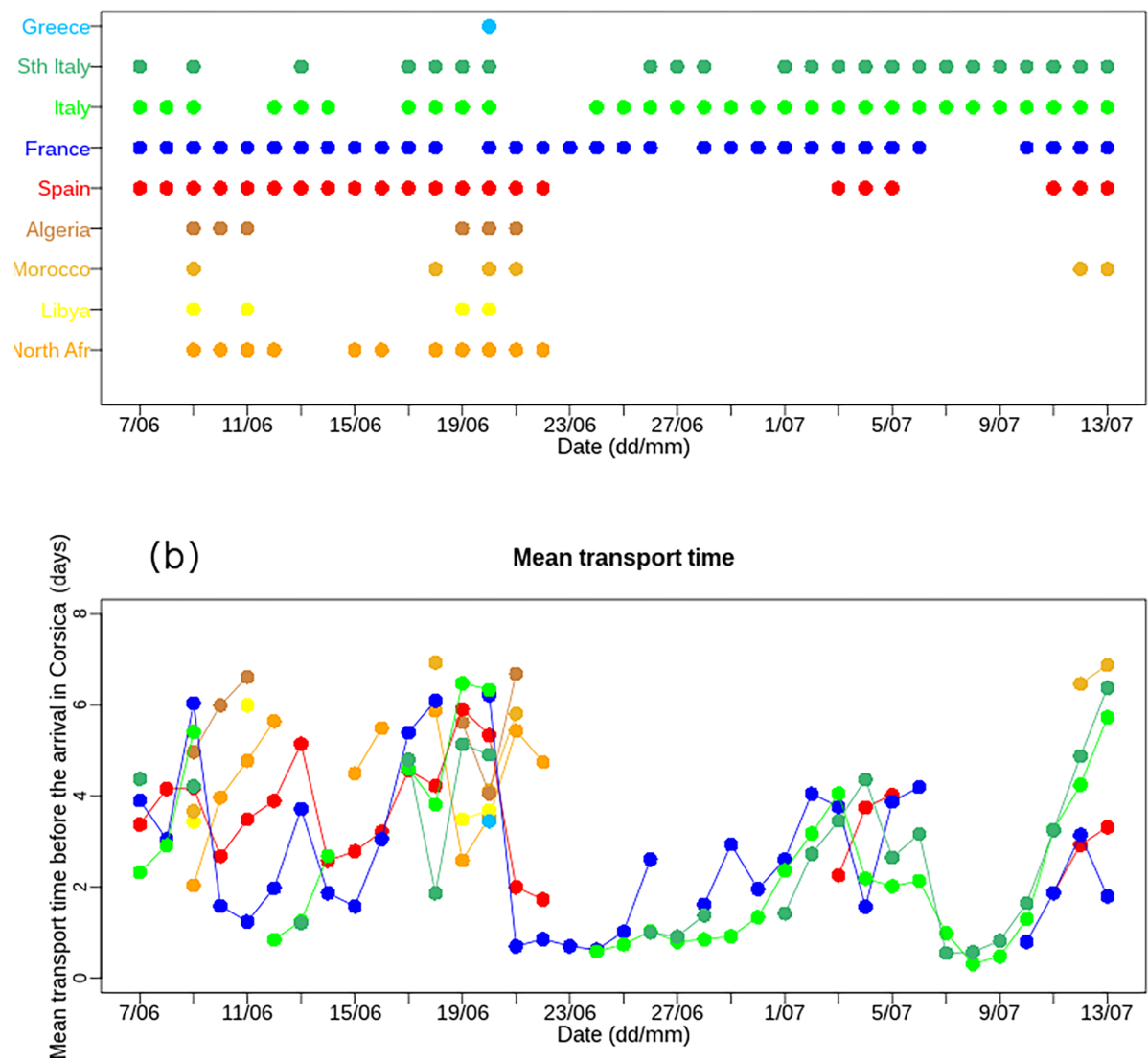

Figure 7. Time series of air mass sources derived from the FLEXPART back-trajectory simulations at $500 \mathrm{~m}$ from 7 June 2013 to 13 July 2013. The top panel (a) represents the passage of an air mass through the different zones before they reached Ersa. Panel (b) represents the transport time of the air masses from each zone in (a) to Ersa.

Table 1. Transport time (mean \pm standard deviation) from the Gulf of Lion and North Atlantic Ocean to the Ersa station obtained from FLEXPART simulations analyses (see Sect. 3.1.1).

\begin{tabular}{lrrrrr}
\hline & 22 June & 23 June & 24 June & 25 June & 26 June \\
\hline $\begin{array}{l}\text { Gulf of Lion: mean transport time } \\
\text { (days) }\end{array}$ & $0.72 \pm 0.69$ & $0.49 \pm 0.29$ & $0.21 \pm 0.09$ & $0.55 \pm 0.30$ & $1.32 \pm 0.50$ \\
\hline $\begin{array}{l}\text { North Atlantic Ocean: mean transport time } \\
\text { (days) }\end{array}$ & $2.88 \pm 0.87$ & $2.50 \pm 0.72$ & $2.94 \pm 1.5$ & $3.23 \pm 1.26$ & $4.45 \pm 1.22$ \\
\hline
\end{tabular}

tions reveal that these air masses were also influenced by anthropogenic sources from France and Italy. The study of the transport of air masses passing over maritime zones (Fig. 7b), especially the Gulf of Lion and North Atlantic zones, gives us information about the transport time from the source regions to Ersa and the changes in altitude. Our simulations indicate that the mean transport time from the Gulf of Lion is less than a day for the whole period except for the last day, 26 June. Whereas from the North Atlantic zone (Bay of Biscay), the transport time is more than 2.5 days and increases up to 4.5 days for 26 June (Table 1). Almost no precipitation occurred during this period between the Bay of Biscay and Corsica, so these air masses were likely not impacted by wet scavenging.

The mean altitude for the air masses coming from the Gulf of Lion is close to $1000 \mathrm{~m}(972 \mathrm{~m} \pm 753)$ for the 5 days, with minima mainly below $500 \mathrm{~m}$, while the mean altitude from the North Atlantic is $1374 \mathrm{~m}( \pm 828)$ and the minimum is below $800 \mathrm{~m}$ only for the first 3 days. Tsyro et al. (2011) reported that the concentration of sea salt aerosols associated with emissions was highest up to altitudes of 600$700 \mathrm{~m}$, which typically correspond to the marine boundary 

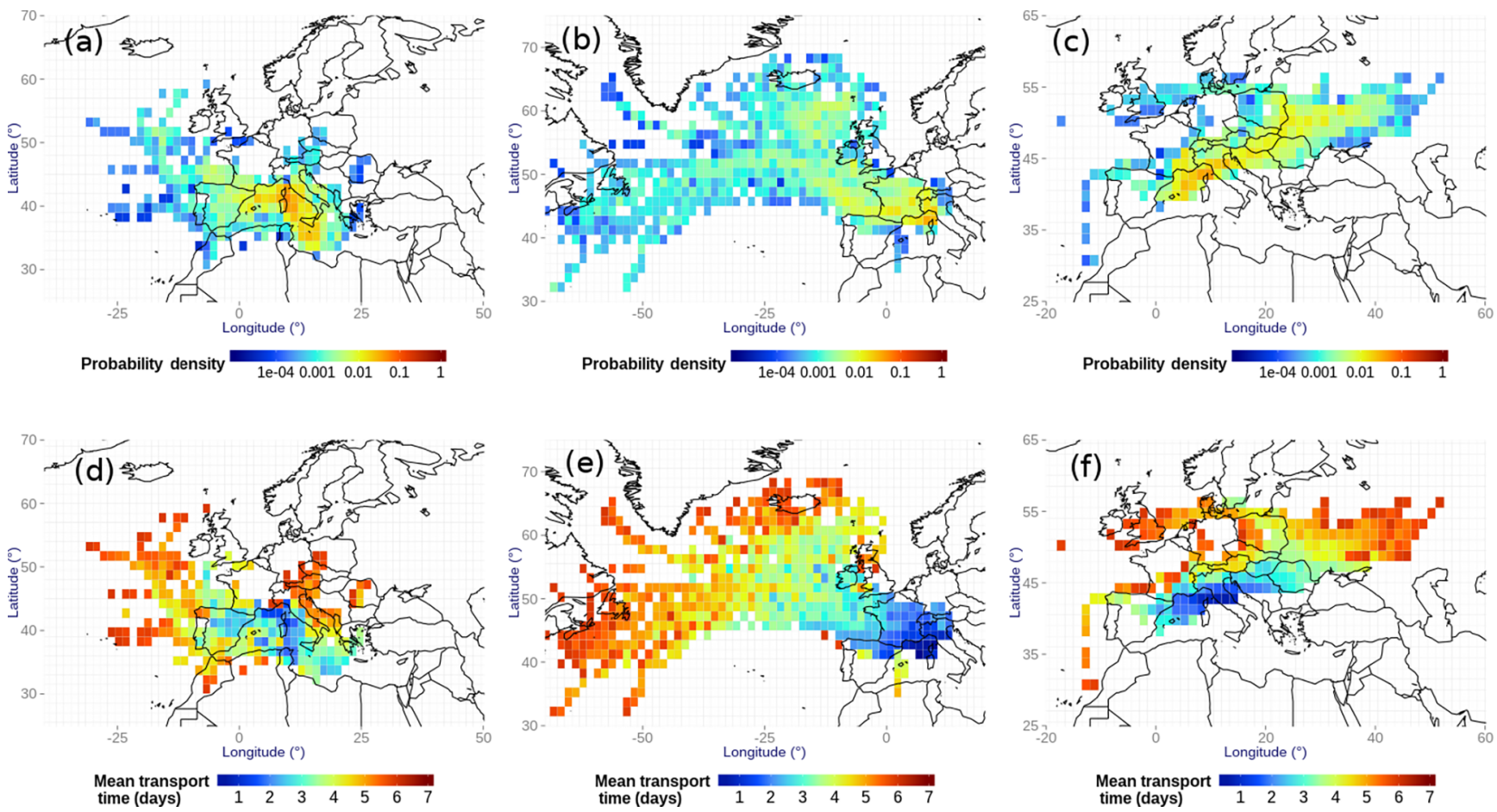

Figure 8. FLEXPART maps representing for $(\mathbf{a}, \mathbf{b}, \mathbf{c})$ the probability density of the back trajectories for the three periods: dust, PMA and BBP. The bottom panels $(\mathbf{d}, \mathbf{e}, \mathbf{f})$ represent the mean transport time from the Ersa station for the three periods: dust, PMA and BBP. Each back trajectory starts at $500 \mathrm{~m}$ from the Ersa measurement site.

layer (MBL) height. Thus an influence from the North Atlantic Ocean would occur more likely during the first 3 days of the period, when the air masses lay within the MBL. Concerning the Gulf of Lion, the altitudes of the air masses are low enough to bring sea salt aerosols in Ersa. While vertical transport is not well captured in the model, the FLEXPART model indicates that most of the PMA aerosol mass is transported in the MBL.

To summarise, our FLEXPART simulations clearly indicate that the Ersa site was impacted by a disperse set of air masses from different regions transporting different types of aerosols. These FLEXPART results are consistent with chemical measurements obtained at Ersa station, as well as the three periods discussed here.

The following sections will focus on the optical, physical and chemical properties of aerosols sampled during the PMA period. The dust and BBP events will be used as a comparison for different states of the atmosphere impacting the Ersa site.

\subsection{Primary marine aerosols}

\subsubsection{PMA ageing}

As reported by Clegg and Brimblecombe (1985) and Quinn and Bates (2005), the ratio of the concentration of $\mathrm{Cl}^{-}$over $\mathrm{Na}^{+}$is an indicator of the chloride depletion that happens when PMAs react with acidic gases like $\mathrm{HNO}_{3}$ and $\mathrm{H}_{2} \mathrm{SO}_{4}$ according to the chemical Reactions (R1, R2, R3):

$$
\begin{aligned}
& \mathrm{H}_{2} \mathrm{SO}_{4}+2 \mathrm{NaCl} \rightarrow \mathrm{Na}_{2} \mathrm{SO}_{4}+2 \mathrm{HCl} \\
& \mathrm{NaCl}+\mathrm{H}_{2} \mathrm{SO}_{4} \rightarrow \mathrm{NaHSO} 4+\mathrm{HCl} \\
& \mathrm{NaCl}+\mathrm{HNO}_{3} \rightarrow \mathrm{HCl}+\mathrm{NaNO}_{3} .
\end{aligned}
$$

These reactions result in a loss of particulate chloride in PMAs during transport. The typical mass ratio of $\mathrm{Cl}^{-} / \mathrm{Na}^{+}$ of the sea water is 1.8 (Lewis and Schwartz, 2004); however, the study of $\mathrm{PM}_{1}$ PMA in the Mediterranean Basin by Schwier et al. (2016) shows a $\mathrm{Cl}^{-} / \mathrm{Na}^{+}$ratio of 1.2. Numerous values are referenced over the Mediterranean Basin: 0.6 for long-term measurements (July 2012-April 2013) in Ersa station (Nicolas, 2013), 0.49 by Mihalopoulos et al. (1997), 1.00 by Koulouri et al. (2008), 1.2 during summer by Bardouki et al. (2003) in Finokalia (eastern Mediterranean, Crete) and 1.2 during summer in the eastern Mediterranean coast of Turquey by Koçak et al. (2004). These values are found to be low compared to the seawater ratio, especially those by Mihalopoulos et al. (1997), which is probably related to the high reactivity of chloride with acidic gases that are present in relatively high concentrations in the Mediterranean atmosphere (Sellegri et al., 2001; Bardouki et al., 2003; Pey et al., 2009). A good correlation was found between $\mathrm{Na}^{+}$mass concentration and the sum of $\mathrm{Cl}^{-}+\mathrm{NO}_{3}^{-}$ 


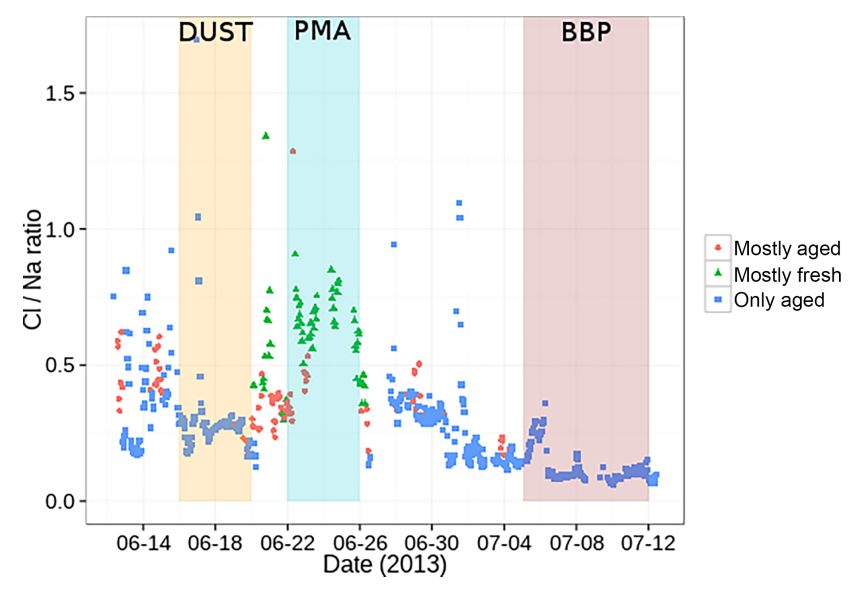

Figure 9. Comparison of the two instruments ATOFMS and PILSIC for inorganic component of sea salt aerosols. The time series represents the mass ratio of chloride to sodium ions calculated from the PILS-IC measurements. The marker colour represents the degree of ageing determined by the ATOFMS.

Table 2. Characteristics of the three log-normal modes of aged sea salt aerosols measured by ATOFMS at Ersa station

\begin{tabular}{lrc}
\hline Mode & $\begin{array}{r}\text { Aerodynamical } \\
\text { diameter } \mu \mathrm{m}\end{array}$ & $\sigma$ \\
\hline 1 & 0.46 & 1.28 \\
2 & 1.13 & 1.35 \\
3 & 1.95 & 1.23 \\
\hline
\end{tabular}

mass concentrations (PM10 measurements; $r^{2}=0.87$ ) indicating that $\mathrm{NO}_{3}^{-}$is the main component that interacts with sea salt.

During the PMA period, the $\mathrm{Cl}^{-} / \mathrm{Na}^{+}$mass ratio varies between 0.13 and 1.3 (Fig. 9), with a mean of $0.59 \pm 0.23$. This result is consistent with the long-term measurement taken between July 2012 and April 2013 at Ersa (Nicolas, 2013). This indicates that PMA measured in Ersa (and throughout the Mediterranean Basin) were predominantly aged.

To distinguish mostly aged and mostly fresh PMA, we used a spectral analysis of the ATOFMS measurements. The terms "fresh" and "aged" PMA, which will be used from now in this text correspond to the classification made with the ATOFMS. During the ChArMEx-ADRIMED campaign, an alternation between these two states of PMA was detected.

The size distribution of these two ATOFMS sea salt types were fitted according to a sum of log-normal modes. The fresh PMA were characterised by one mode with a vacuum aerodynamic diameter of $1.29 \mu \mathrm{m}$ and a standard deviation $\sigma$ of 1.34, while the aged PMA were characterised by three different modes, as detailed in Table 2.

Our results show that during the campaign aged PMA are dominant, but during the PMA period (22-26 June) when the wind near Cap Corse is higher (Sect. 3.2.2), there is an alternation of short events of fresh or aged PMA, with a dominance of fresh PMA. The comparison of the ATOFMS and PILS data show a relatively good agreement between the two instruments regarding the dominance of fresh and aged PMA (Fig. 9).

To compare the two instruments, we looked at the count ratio of aged to fresh PMA, and attributed a state to the $\mathrm{Cl}^{-} / \mathrm{Na}^{+}$ratio measured by the PILS-IC. For a large number of measurements only aged aerosols were detected and were labelled "only aged". When the count ratio of aged aerosols over fresh aerosols was higher than one, the measurements were characterised as mostly aged, and less than one the PMA were considered mostly fresh. One can observe in Fig. 9 that the $\mathrm{Cl}^{-} / \mathrm{Na}^{+}$ratio is higher when the ATOFMS distinguished fresh PMA, and lower when the ATOFMS distinguished aged PMA. We then determined the mean $\mathrm{Cl}^{-} / \mathrm{Na}^{+}$ratio for mostly aged $(0.38 \pm 0.15)$ and mostly fresh PMA $(0.62 \pm 0.17)$. In our observations, the mostly fresh PMA ratio remains low compared to the initial ratio of 1.8 (Lewis and Schwartz, 2004) or even 1.2 for $\mathrm{PM}_{1}$ PMA (Schwier et al., 2016), revealing that even though PMA are characterised as fresh, they have undergone chemical reactions before reaching Ersa station.

\subsubsection{PMA sources}

Complementary to the FLEXPART results, we used wind measurements at the Semaphore station, at the Gulf of Lion buoy and at the Bay of Biscay buoy to investigate the possible relationship between the increase in PMA concentration observed in Ersa and the wind speed at these stations, as well as to better assess the origin of sea salt aerosols at Ersa.

During the ChArMEx-ADRIMED campaign, the majority of analysed air masses containing PMA came locally from the west and the concentration of marine particles increased with wind speed (Fig. 10a). The wind direction is constant around $270^{\circ}$ for 6 days (21-26 June), and fluctuates afterwards between eastern and western origins. The maximum wind speed $\left(20 \mathrm{~m} \mathrm{~s}^{-1}\right)$ encountered during the campaign was observed on 24 June, coinciding with the highest sea salt mass concentration measured.

To investigate the relationship between wind speed and concentration of PMA measured in Ersa, we averaged its concentration by wind bins of $1 \mathrm{~m} \mathrm{~s}^{-1}$ for different cases. We first looked at the relationship between the concentration of PMA in Ersa and the wind speed measured at the Semaphore for the whole period of the campaign (Fig. 10a). The result indicates a relationship between the wind speed and PMA concentration and the best fit $\left(r^{2}=0.92\right)$ is presented in the form of $\ln [\mathrm{PMA}]=a \times \mathrm{WS}+\ln \left(M_{0}\right)$, where WS corresponds to the wind speed and $M_{0}\left(\mu \mathrm{g} \mathrm{m}^{-3}\right)$ to the concentration that corresponds to a wind speed $\mathrm{WS}=0$. The error bars correspond to $2 \sigma \mathrm{rms}$ (root mean square). Above $13 \mathrm{~m} \mathrm{~s}^{-1}$, the concentration starts to rise rapidly. The re- 

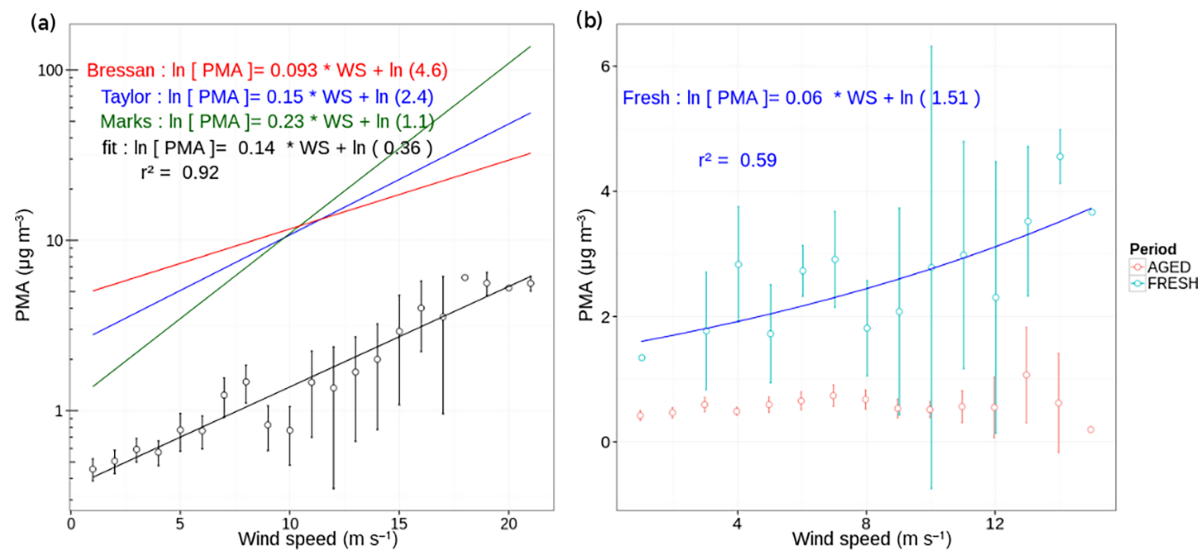

Figure 10. PMA concentration measured at Ersa as a function of wind speed for the ADRIMED period. The PMA concentrations have been averaged by wind speed bins of $1 \mathrm{~m} \mathrm{~s}^{-1}$. The error bars represent $\pm 2 \sigma / \sqrt{N}$ ( $N$ is the number of independent measurements). (a) The black curve correspond to measurements, while the red, blue and green curves correspond to fits parameters by Bressan and Lepple (1985); Taylor and Wu (1992); Marks (1990). Panel (b) represents fresh (blue curve) and aged (red curve) PMA over the whole campaign.

lationship described here is compared with fit parameters found by Bressan and Lepple (1985), Taylor and Wu (1992); Marks (1990); Lewis and Schwartz (2004) and chosen because the time resolution of the measurements were similar to those in Ersa and wind speed encountered during their measurements were in the same range as in Ersa during the campaign. Despite the high correlation between PMA concentration and wind speed shown here, our results yield mass concentrations at least an order of magnitude lower than other studies shown in Fig. 10. This difference is probably related to the sampling altitudes, which for our study was 533, and $\sim 10 \mathrm{~m}$ a.s.l. for Bressan and Lepple (1985); Taylor and $\mathrm{Wu}(1992)$ and Marks (1990). This is contrary to Fomba et al. (2014), who did not find a significant correlation between PMA concentrations and wind speed in Cabo Verde, even though they found an increase of PMA concentration on days of higher wind speeds. Sellegri et al. (2001) had difficulties establishing a relationship between local emissions of PMA and wind speed measurements using instrumentation with a long integration time during the FETCH campaign, in accordance with previous results of Quinn et al. (2000). Shinozuka et al. (2004) found that wind speed was a good indicator for a measuring period but not for a specific case.

To investigate the origin of PMAs as a function of their ageing, we distinguished the air masses that contain fresh or aged PMA, using the method defined in Sect. 3.2.1, for the whole campaign. We observe that the concentration of aged PMA (Fig. 10b) is constant and does not depend on the local wind speed, which suggest that the Ersa site is always impacted by long-range transport containing aged PMA, even if the concentration is low $\left(0.6 \pm 0.2 \mu \mathrm{g} \mathrm{m}^{-3}\right)$. On the contrary, we observe that fresh PMA concentration measured at Ersa (Fig. 10b) is highly dependant on the wind speed, following a fit of the form $\ln [\mathrm{PMA}]=a \times \mathrm{WS}+\ln \left(M_{0}\right)$ with a correct correlation $\left(r^{2}=0.59\right)$. This result indicates that the highest concentration of PMA measured in Ersa during the campaign corresponds to fresher aerosols and is dependent on the local meteorological conditions.

We then compared the wind speed at the two probable regions of emission, the Gulf of Lion and the Bay of Biscay, to the concentration of PMA, using FLEXPART results, for the PMA period (22-26 June). To account for the transport time of PMA, we added a delay of $12 \mathrm{~h}$, which corresponds to the mean transport time from the Gulf of Lion to Ersa modelled with FLEXPART for the PMA period, and $60 \mathrm{~h}$ for the Bay of Biscay (Fig. 11b and c). This work was done for the PMA period from 22 to 26 June. In Fig. 11a, the correlation between the mass concentration of PMA and the wind speed at Ersa is good for fresh PMA ( $r^{2}=0.71$; Fig. 11a) as presented in the previous paragraph for the whole campaign. For the Gulf of Lion (Fig. 11b), the correlation is good for aged PMA (red curve, $r^{2}=0.87$ ) while there is no correlation following this fit for fresh PMA and wind speed at the Gulf of Lion. The same analysis was done for the Bay of Biscay (Fig. 11c) but no correlation was found for fresh, aged PMA or all the PMA regardless of their ageing.

According to these results, during the PMA period, the PMA that were measured in Ersa were a mixture of fresh PMA emitted near the Ersa station and of aged PMA emitted from the Gulf of Lion. It should be noted that measurements of PMA have also been made when the air masses were coming from the east, but the concentrations were lower $\left(<2 \mu \mathrm{g} \mathrm{m}^{-3}\right)$.

From these results, the most probable zone that brings PMA to Ersa during ADRIMED regarding altitude, transport time of air masses and local wind speed would be the Gulf of Lion and the sea close to Ersa, considering that the buoy at the Bay of Biscay represents the wind speed of the area. Beyond the scope of this work, an analysis of the emission 

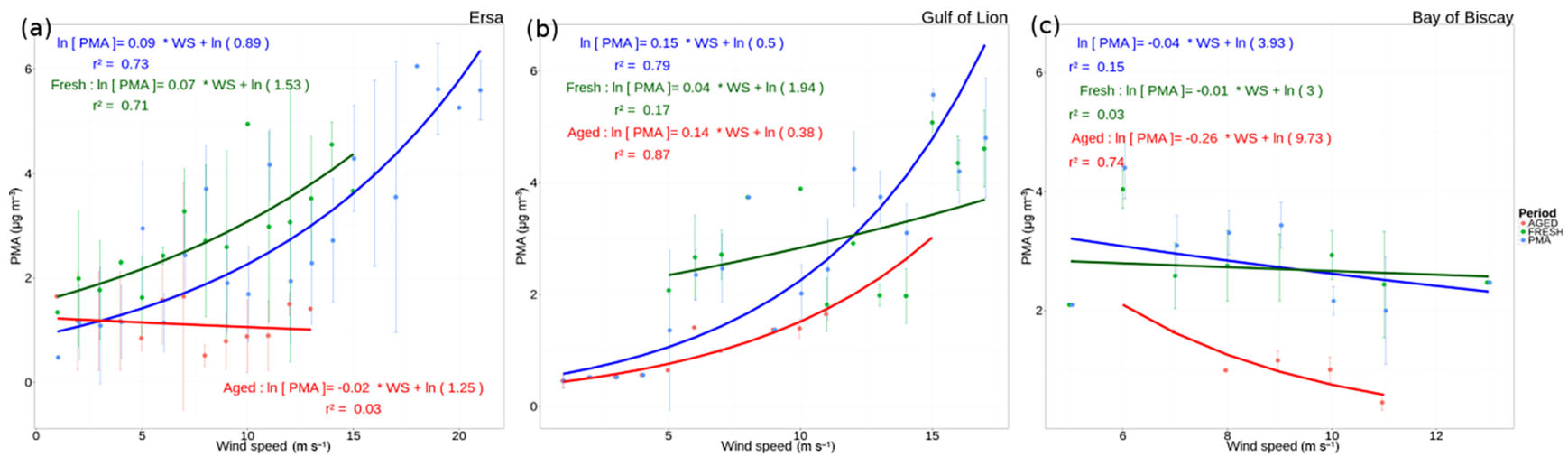

Figure 11. Concentration of sea salt aerosols measured by the PILS IC as a function of wind speed measured at Ersa (a), at the Gulf of Lion buoy (b) and at the Bay of Biscay buoy (c), for the PMA period. Offsets of $12 \mathrm{~h}$ and $60 \mathrm{~h}$ have been applied between the wind speed measurements in the Gulf of Lion and the Bay of Biscay respectively and the PMA concentrations observed at Ersa to account for transport time of the air masses. The PMA concentrations have been averaged by wind speed bins of $1 \mathrm{~m} \mathrm{~s}^{-1}$. The error bars represent $\pm 2 \sigma / \sqrt{N}$. Blue curves represents all the PMA measurements, while green and red curves represent fresh and aged PMA.

and transport of marine aerosols during this PMA period is ongoing and uses the Meso-NH model.

\subsubsection{PMA physical properties in comparison with dust and BBP periods}

This PMA period represents the background atmospheric conditions that affect Ersa most of the time. In this section, after an overview of the ADRIMED field campaign, the number and volume size distribution of PMA are investigated, as they are fundamental parameters which estimate the aerosol radiative effects. A comparison with two sporadic events (dust and BBP), which influence Ersa principally in spring and summer, is also carried out.

The total number concentration (CPC + OPS) during the campaign observes a mean value of $1900 \pm 920 \mathrm{~cm}^{-3}$ with several short episodes (few hours) of high concentrations $\left(>5000 \mathrm{~cm}^{-3}\right)$ at the end of June. Thus, the background number concentration is higher than what is usually measured at a pristine marine site $\left(300-600 \mathrm{~cm}^{-3}\right.$; D O'Dowd and De Leeuw, 2007) and denotes contamination by other sources, principally from continental Europe, as Ersa is not affected by immediately local sources. In parallel, the number size distributions measured by the SMPS show that the particles detected during these short episodes of high concentration have diameters below $50 \mathrm{~nm}$ and probably correspond to new particles during transport over the Mediterranean sea.

During this field campaign, the fine and accumulation modes $(10 \mathrm{~nm}<\mathrm{Dp}<600 \mathrm{~nm})$ were dominant in number. Furthermore, the concentration of these two modes rises at the beginning of July, particularly the accumulation mode, following the scheme already mentioned in the previous section for $\mathrm{PM}_{1}$ particles. Hence, the ratio of the number concentration from 4 to 13 July over the number concentration from 6 June to 3 July is greater than 2 for particle diameters greater than 0.24 and $0.52 \mu \mathrm{m}$. This ratio reaches its highest value for particles with diameters of $0.4 \mu \mathrm{m}$.

Before conducting comparisons on the physical properties of sea salt, the PMA period was divided into several shorter periods according to their ageing (see Sect. 3.2.1), that will be called "ageing periods". In addition, we chose a supplementary period (1-4 July) corresponding to low PMA concentration when it does not exceed the background concentration $\left(0.76 \mu \mathrm{g} \mathrm{m}^{-3}\right)$. The number and volume size distribution were averaged over the ageing periods and fitted under the assumption that the distribution is a sum of log-normal modes to investigate whether the ageing of PMA could be characterised by their size distributions. Three to six modes were necessary to fit the observed dry size distributions.

For the number size distribution, a large variety of Aitken and accumulation mode can be derived when comparing the different periods. They show a large variety of diameters and concentration whether they contain low or high PMA concentration, aged or fresh. However, a coarse mode (modal diameter of $1.2 \mu \mathrm{m}$ ) appears for all the size distributions containing PMA, for both aged and fresh aerosols. This mode does not exist when the concentration of PMA is within the background. The concentration of this mode seems to be higher for fresh than aged PMA which is probably due to dry deposition during transport. As we did not find any significant difference between the size distributions of aged and fresh PMA, they are merged for the sequence of the analysis as PMA size distribution over the PMA period.

The number and volume size distribution have been averaged for each periods: dust, PMA and BBP (Fig. 12). We chose to average the most intense part of each period to extract the representative properties of each aerosol type. Thus, although the dust event starts on 16 and ends on 20 June, we analysed the size distribution obtained from 17:00 to 19 June at 00:00 UTC. Likewise, the study of the size distribution 
Table 3. Characteristics of the fit by a log-normal distribution $(N, d, \sigma)$ for the three periods: dust, PMA and BBP

\begin{tabular}{|c|c|c|c|c|c|c|c|c|c|c|c|c|}
\hline Number concentration & $N_{1}$ & $d_{1}$ & $\sigma_{1}$ & $\mathrm{~N}_{2}$ & $d_{2}$ & $\sigma_{2}$ & $N_{3}$ & $d_{3}$ & $\sigma_{3}$ & $N_{4}$ & $d_{4}$ & $\sigma_{4}$ \\
\hline Dust & 156 & 0.06 & 1.88 & 389 & 0.13 & 1.51 & 0.11 & 1.16 & 1.3 & 0.02 & 3 & 1.47 \\
\hline PMA & 1162 & 0.04 & 1.46 & 164 & 0.13 & 1.56 & 0.45 & 1.2 & 1.5 & 0.02 & 5.4 & 1.25 \\
\hline $\mathrm{BBP}$ & 0.13 & 0.027 & 0.9 & 582 & 0.08 & 1.79 & 170 & 0.22 & 1.35 & 0.07 & 1.5 & 1.7 \\
\hline Volume concentration & $V_{1}$ & $d_{1}$ & $\sigma_{1}$ & $V_{2}$ & $d_{2}$ & $\sigma_{2}$ & $V_{3}$ & $d_{3}$ & $\sigma_{3}$ & $V_{4}$ & $d_{4}$ & $\sigma_{4}$ \\
\hline Dust & 0.5 & 0.18 & 1.46 & 0.64 & 0.26 & 1.43 & 0.43 & 2.36 & 1.62 & & & \\
\hline PMA & 0.09 & 0.07 & 1.47 & 0.44 & 0.24 & 1.54 & 1.02 & 1.64 & 1.71 & 0.18 & 6.66 & 1.34 \\
\hline BBP & 0.77 & 0.2 & 1.54 & 1.34 & 0.32 & 1.33 & 0.31 & 2.24 & 1.55 & 0.2 & 6.13 & 1.36 \\
\hline
\end{tabular}
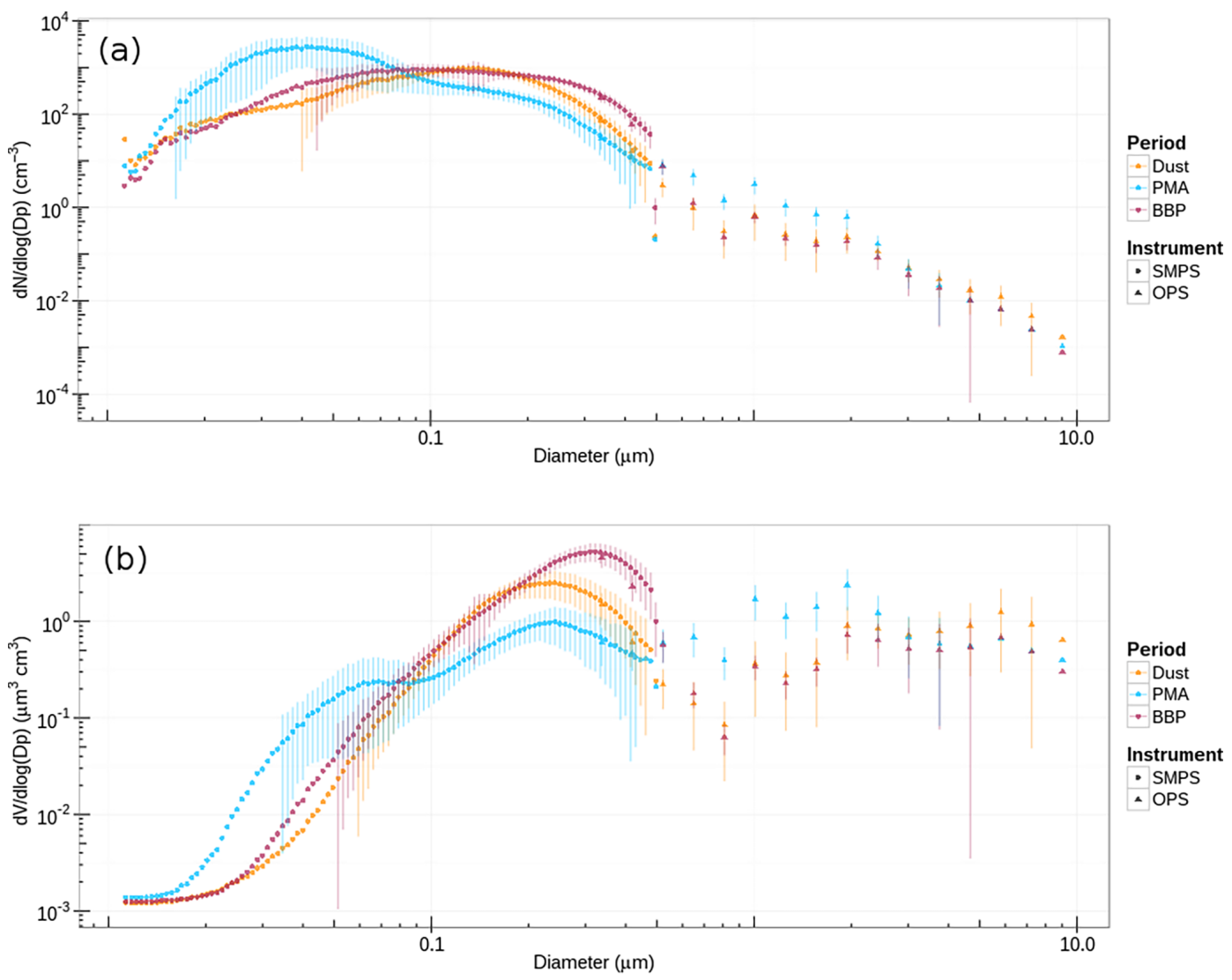

Figure 12. Number (a) and volume (b) size distribution averaged by periods of dust, PMA, and BBP using the SMPS and OPS instruments. The dry diameters range $10 \mathrm{~nm}$ to $10 \mu \mathrm{m}$. The first and last days of each period were removed to capture the main feature and the maximum amplitude of the event.

for PMA and BBP aerosols are from 23 June at 00:00 to 25 June at 00:00 UTC and from 9 July at 00:00 to 11 July 0:00 UTC respectively. The results are summarised in Table 3. The highest number concentration for PMA period was for particles of modal diameter of $40 \mathrm{~nm}$, followed by a mode at $130 \mathrm{~nm}$ and a third mode at $1.2 \mu \mathrm{m}$. We find a good agreement of modal diameters with the size distribution measured by Ovadnevaite et al. (2014) in the parameterisation of the emission of PMA from the Atlantic Ocean. Furthermore, our results agree with measurements taken in the
Mediterranean Sea by Schwier et al. (2015). We observed a high number concentration of fine particles during the PMA period, which is consistent with measurements reported in Fig. 12 a. The modal diameter of these fine particles is situated at $40 \mathrm{~nm}$. This mode was also measured by Schwier et al. (2015) at $d=37.5 \mathrm{~nm} \pm 1.4$ during PMA flux measurements from Mediterranean waters. The second mode has a modal diameter of $130 \mathrm{~nm}$, which is somewhat higher than the $90 \mathrm{~nm}$ mode found by Schwier et al. (2015), which is related to the presence of aged particles during our study. 


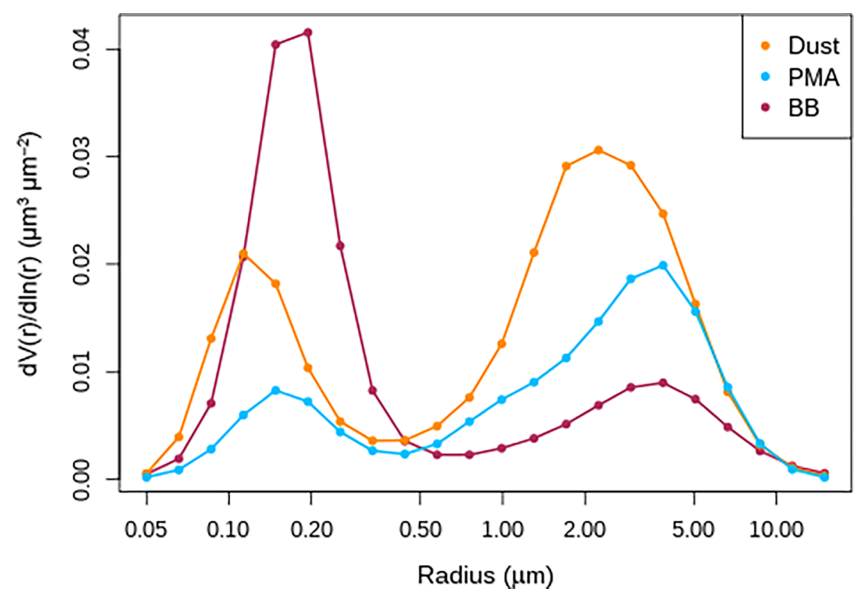

Figure 13. AERONET volume size distributions averaged for the three periods.

We find important distinctions between the three different periods reported in Fig. 12a. As expected, during the dust event, the number size distribution is higher for the largest particles ( 3 to $10 \mu \mathrm{m}$ size range). During the BBP period, the dominant mode of the number size distribution is located around $200 \mathrm{~nm}$ and the number concentration of particles greater than $500 \mathrm{~nm}$ is found to be low $\left(65 \pm 14 \mathrm{~cm}^{-3}\right)$. This result is consistent with the typical number concentration of biomass burning aerosols that peaks in the size range of 100-200 nm (Guyon et al., 2005; Reid et al., 2005; Andreae, 2007). These hydrophilic aerosols are subject to increases in size when they age during transport (Andreae and Rosenfeld, 2008), which is consistent with our observations of a mode centred at $200 \mathrm{~nm}$ as they were transported for 34 days before reaching Ersa.

Looking at the volume size distribution is a way to distinguish the particles that have the greatest impact on mass concentration, i.e. the coarser particles. On average, during the ADRIMED period the mean total volume concentration (CPC + OPS) is $40 \pm 16 \mu \mathrm{m}^{3} \mathrm{~cm}^{-3}$, and the volume concentration of smallest particles $(d<500 \mathrm{~nm})$ is $22 \pm 11 \mathrm{\mu m}^{3} \mathrm{~cm}^{-3}$, while that of the coarser particles $(d>500 \mathrm{~nm})$ is $16 \pm 9 \mu \mathrm{m}^{3} \mathrm{~cm}^{-3}$.

The volume size distribution shows different patterns for the dust, PMA and BBP periods. We distinguish a coarser mode between 20 and 27 June, including the PMA period, with a modal diameter of $1.6 \mu \mathrm{m}$. Marine aerosols with diameters greater than $1 \mu \mathrm{m}$ are largely inorganic sea salt (O'Dowd et al., 2004). A coarse mode is also observed around 19 June (dust period) with diameters between 5 and $7 \mu \mathrm{m}$, which probably corresponds to mineral dust particles in accordance with the volume size distributions measured on board the ATR-42 aircraft (Denjean et al., 2016). Figure 12b shows two dominant modes during the dust period: one at a dry diameter of $0.18 \mu \mathrm{m}$ and the second one around $2.4 \mu \mathrm{m}$. Finally, the BBP event is found to be dominated by a mode at $320 \mathrm{~nm}$, and the volume concentration of the coarse mode is here very low.

We have also compared the results of the in situ surface volume size distributions with AERONET/PHOTONS retrievals (Fig. 13). AERONET data are compared with the in situ measurements, as they are derived from an algorithm, averaged over a few days and have a limited number of measurements (seven available for the PMA period). Concerning dust and PMA periods, the coarse modes measured by OPS and SMPS are consistent with the atmospheric column volume size distribution and contribute to the largest fraction of aerosol mass, even though a fine mode is also detected during dust periods. During the BBP period, both observations (in situ and AERONET) clearly indicate volume size distributions that are largely dominated by the fine mode. The difference of size distribution between the three periods is higher for AERONET data than for the in situ data. For the dust period, the reason is that the main part of the dust plume was situated at an altitude of 3 to $6 \mathrm{~km}$. For the PMA period, the hygroscopic growth of marine aerosols can explain a shift in the diameter modes. There also might be a loss of supermicron mode particles before they reach the OPS, which has an impact on the PMA and dust periods.

These three periods are characterised by different volume size distributions (in situ measurements), as summarised in Table 3. The dust and PMA periods are characterised by coarser particles, with a modal diameter of 2.4 and $1.6 \mu \mathrm{m}$ respectively, while the BBP period is characterised by particles in the accumulation mode with modal diameter of $320 \mathrm{~nm}$.

\subsubsection{PMA optical properties and local shortwave direct radiative effect in comparison with dust and BBP periods}

In addition to chemical and size distribution aerosol properties, we also determined optical properties, providing AOD at the measuring site, as well as the SSA and AE obtained for the whole atmospheric column from AERONET/PHOTONS observations (Dubovik et al., 2002b) and their spectral dependences in the solar spectral region. These results are summarised in Table 4. As in the previous part, a comparison with dust and BBP period was also realised.

First, the AOD retrievals provide information about the loading of aerosols within the atmospheric column. During the ChArMEx-ADRIMED campaign, AOD (at $500 \mathrm{~nm}$ ) was found to be moderate, with an average of $0.15 \pm 0.08$ (Fig. 14a). Such values are consistent with the site location and aerosol concentration (see Sect. 3.3.1), Ersa not being impacted by local pollution or high anthropogenic sources. In that sense, the AOD background is low, typical of a rural site. However, from the beginning of July to the end of the campaign, the AOD increases to values up to 0.6 with a higher wavelength dependency.

AOD is lowest during the PMA event (22-26 June), with a mean value of $0.11 \pm 0.08$ at $500 \mathrm{~nm}$, close to those re- 
Table 4. Summary of the optical properties (mean and standard deviation) estimated for the three different aerosols regimes: AOD, AE, SSA, scattering coefficient (in $\mathrm{Mm}^{-1}$ ), and instantaneous TOA and BOA radiative effect (in $\mathrm{W} \mathrm{m}^{-2}$ )

\begin{tabular}{lrrrrrr}
\hline & $\begin{array}{r}\text { AOD } \\
500 \mathrm{~nm}\end{array}$ & $\begin{array}{r}\text { AE } \\
440-870 \mathrm{~nm}\end{array}$ & $\begin{array}{r}\text { SSA } \\
440 \mathrm{~nm}\end{array}$ & $\begin{array}{r}\text { Scattering coefficient } \\
550 \mathrm{~nm}\end{array}$ & TOA & BOA \\
\hline Dust & $0.16 \pm 0.08$ & $1.4 \pm 0.3$ & $0.97 \pm 0.03$ & $28 \pm 11$ & $-14 \pm 6$ & $-21 \pm 11$ \\
PMA & $0.11 \pm 0.08$ & $1.3 \pm 0.4$ & $0.98 \pm 0.02$ & $28 \pm 11$ & $-8 \pm 3$ & $-11 \pm 4$ \\
BBP & $0.23 \pm 0.07$ & $2.1 \pm 0.2$ & $0.98 \pm 0.03$ & $54 \pm 18$ & $-15 \pm 4$ & $-23 \pm 6$ \\
ADRIMED & $0.17 \pm 0.1$ & $1.7 \pm 0.5$ & $0.98 \pm 0.03$ & $37 \pm 20$ & $-12 \pm 5$ & $-17 \pm 8$ \\
\hline
\end{tabular}

ported over the Mediterranean Basin (Smirnov et al., 2002; Pace et al., 2006; Fotiadi et al., 2006). Smirnov et al. (1995) found that for clean oceanic conditions, AOD was below 0.1 (at $550 \mathrm{~nm}$ ) and Pace et al. (2006) found an average value of 0.11 for the same marine conditions. In the Mediterranean sea in particular, Fotiadi et al. (2006) reported a value of 0.15 in Crete in the background corresponding to marine aerosols and Mishra et al. (2014) found a mean AOD over the eastern Mediterranean for marine aerosols (June-August 2010) of $0.06 \pm 0.01$. Furthermore, it should be noted that AOD is not very sensitive to the wavelengths during these 5 days due to the presence of coarse particles.

AOD is higher during the dust event, reaching 0.3 (at $500 \mathrm{~nm}$; Fig. 14), corresponding to a relatively low value for a dust outbreak occurring over the Mediterranean Basin (Mallet et al., 2016). AOD can reach values above one (Guerrero-Rascado et al., 2009, over the western Mediterranean) and even up to two (Di Sarra et al., 2011 over Lampedusa). As observed during the PMA period, AOD is not sensitive to wavelengths during the dust event, denoting the presence of coarse particles. AOD showed a very different pattern during the last part of the campaign, reaching higher values and showing a strong dependence to the wavelengths. AOD thus exceeds 0.4 in the middle of July and is higher for shorter wavelengths. It denotes a significant contribution of small particles to the solar extinction, in accordance with the SMPS and TEOM $\mathrm{PM}_{1}$ observations previously presented and during the BBP period. The AOD values are much higher for these two periods than for the PMA period.

For the PMA episode, AE varied between 0.4 and 2, with a mean value of 1.3 , which is below the mean value of the ADRIMED campaign (1.8; Fig. 14b). AE also decreased to 1.15 for 24 June, when PMA concentration is highest. Such a value is characteristic of clean ocean regions as reported by Smirnov et al. (2002), who found values between 0.3 and 0.7. In addition, Pace et al. (2006) and Fotiadi et al. (2006) reported AE between 0.7 and 1 for background marine atmosphere over the central and eastern Mediterranean. The AE measured at the Ersa station during the PMA event is not as low as these referenced values and could indicate a possible mixing between sea salt and other aerosols, as the western Mediterranean is under the permanent influence of continental sources. This point is also consistent with the observed number size distribution, which showed that the number concentration of fine particles was high during the PMA event, indicating pollution particles from the European continent.

A high variability was also found during dust periods. Indeed, AE fluctuated between 1 and 2. These are not typical values observed for desert dust particles, which generally tend toward values less than one, denoting a majority of coarse particles (Dubovik et al., 2002a). In that sense, the higher values observed at Ersa could be due to the possible mixing of particles in the atmosphere during these days, by the weak intensity of the dust outbreak observed during ADRIMED or by the possible deposition of the coarser dust particles during transport. Finally, and during the BBP period, $\mathrm{AE}$ was found to be mostly above two. Its pattern follows a clear diurnal variation, with a maximum around 12:00 UTC and a minimum in the beginning and in the end of the day. AE observed during this period is stable for almost a week, from 4 to 10 July. The largest difference noted for AE between dust, PMA and BBP periods is in their internal variability. For the first two periods, a mixing and high variability is found while for the last period, $\mathrm{AE}$ is constant for more than 5 days, showing that the atmosphere is mostly under the influence of the same aerosol type.

Overall, SSA observed during the campaign remained relatively high, with values above 0.90 for most of the period, associated with a spectral dependence less than 0.05 (from 440 to $870 \mathrm{~nm}$ ). In that sense, the presence of absorbing particles is shown to be sporadic and lasted no more than a few hours. During the PMA period, SSA was found close to unity (mean of $0.98 \pm 0.02$; not shown here), indicating significant scattering optical properties, consistent with marine aerosols optical properties in the solar range (Lewis and Schwartz, 2004). During the dust period 16-20 June, SSA decreased to values between 0.90 and 0.95 (at $440 \mathrm{~nm}$ ), indicating moderate absorbing properties, which are characteristics of desert dust over the Mediterranean Basin (Mallet et al., 2013). Finally, during the BBP period, we observed a higher wavelength dependency, with SSA values oscillating between 0.90 and 1.0 (at $440 \mathrm{~nm}$ ).

In addition to the atmospheric column information, over the entire period of the campaign, nephelometer measurements reveal that the scattering due to particles was relatively low (mean of $37 \mathrm{Mm}^{-1} \pm 20$, at $550 \mathrm{~nm}$ ) and not sensitive to 

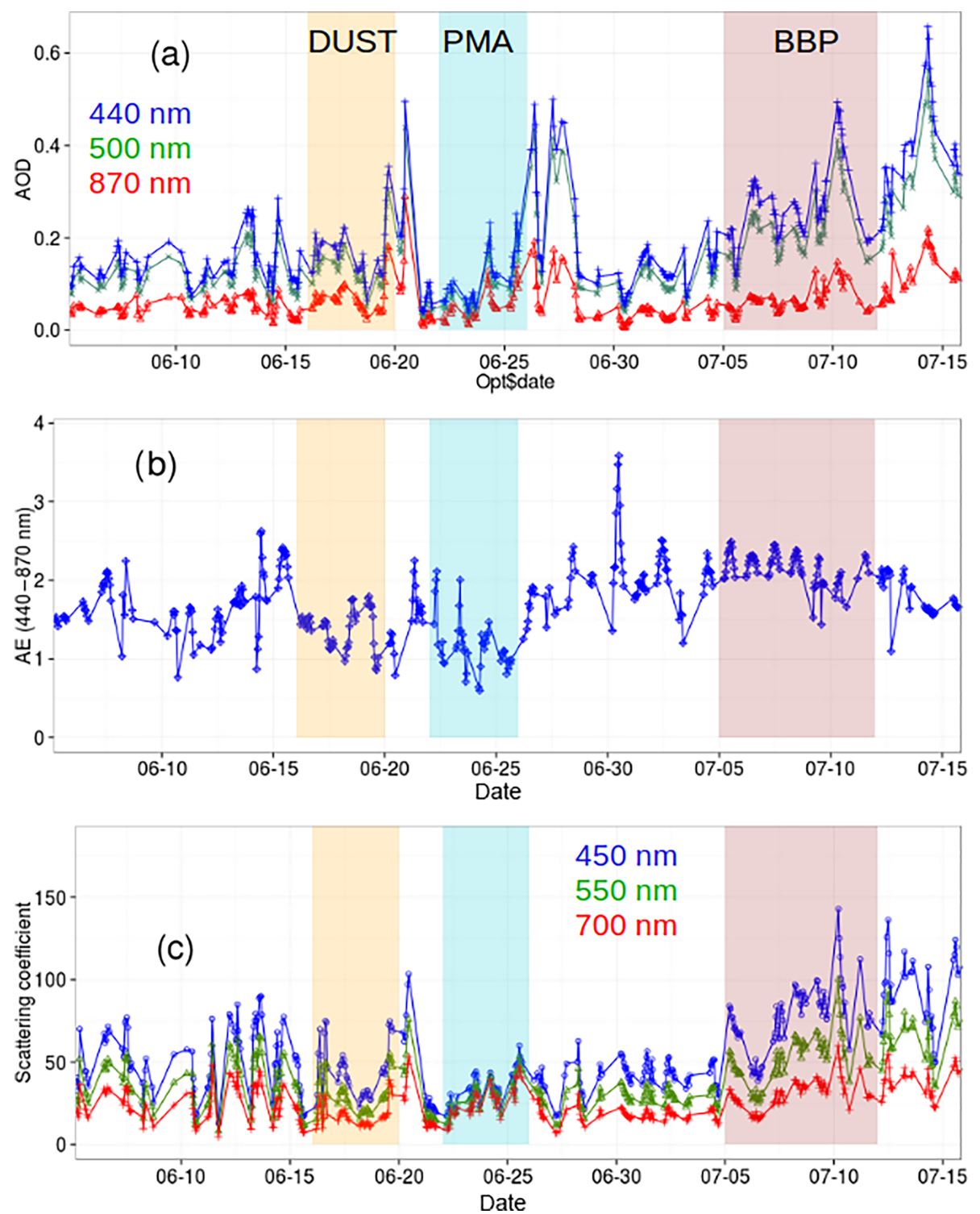

Figure 14. Time series of (a) aerosol optical depth (AOD) at three wavelengths (440, 500 and 870 nm) measured by the radiometer from the AERONET network situated at the Semaphore during the ADRIMED campaign, (b) Angström exponent calculated from AERONET data, during the ADRIMED campaign, using the extinction measurements at 440 and $870 \mathrm{~nm}$, (c) Scattering coefficient at three wavelengths: $450 \mathrm{~nm}$ (blue), $550 \mathrm{~nm}$ (green) and $700 \mathrm{~nm}$ (red) measured by the nephelometer situated at Ersa.

wavelength during June, particularly during dust and PMA periods (Fig. 14c). This is in contrast to July, when higher scattering coefficients (mean of $48 \mathrm{Mm}^{-1} \pm 24$ ) associated with higher AE (AE July mean of $2.1 \pm 0.2$, AE June mean of $1.6 \pm 0.5)$ are observed.

During dust and PMA period, the scattering coefficient remains low (mean of $28 \pm 11$ and $28 \pm 11 \mathrm{Mm}^{-1}$ respectively). The PMA period is characterised by a relatively weak wavelength dependency (Fig. 14c). While the mixing of dust with fine particles, previously shown by the AERONET volume size distribution, is shown here by a relatively high wavelength dependency (mean of $20 \pm 9 \mathrm{Mm}^{-1}$ ). On the contrary, during the BBP period, the wavelength dependency is highest (mean of $49 \pm 15 \mathrm{Mm}^{-1}$ between 450 and $700 \mathrm{~nm}$ ), and the scattering coefficient reaches its highest values (up to $137 \mathrm{Mm}^{-1}$ ). This clearly indicates that aerosols are smaller in size during this period, which is consistent with AERONET/PHOTONS data and $\mathrm{PM}_{1}$ concentrations obtained at Ersa station.

The optical characteristics (AOD, SSA and AE) of the air masses during the PMA event are found to be consistent with the literature (Smirnov et al., 2002; Pace et al., 2006), even though a mixing with continental fine particles was also detected. 

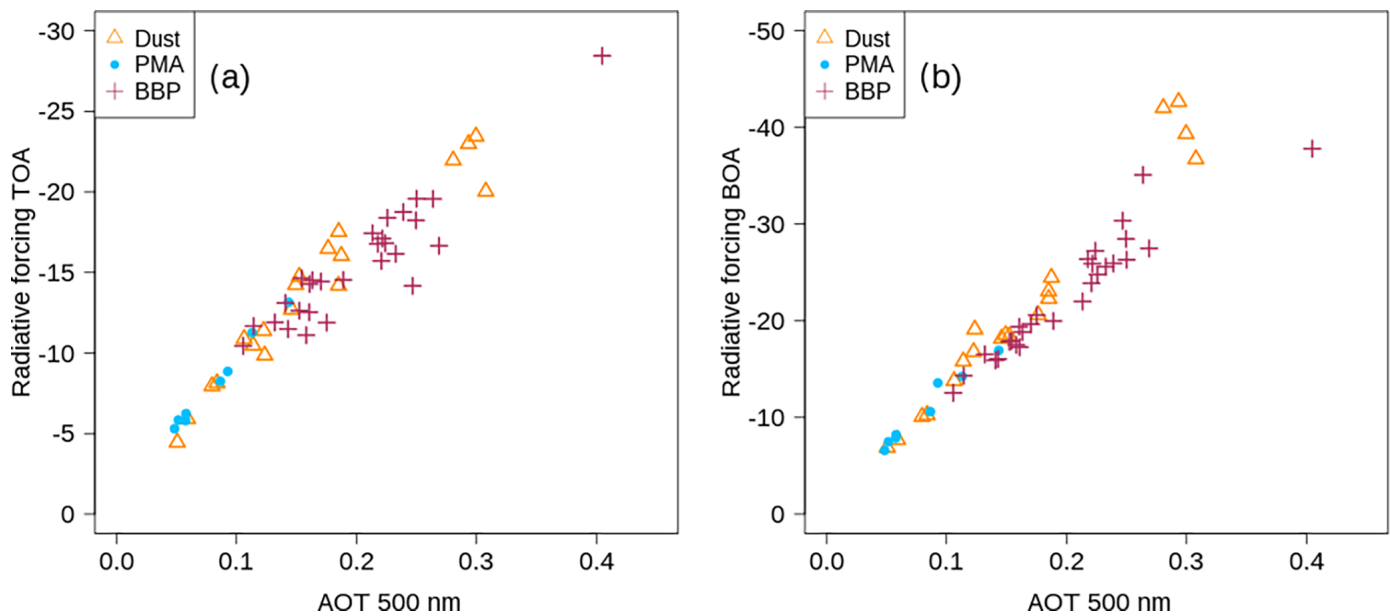

Figure 15. Aerosol radiative effect at (a) the top of the atmosphere (TOA) and (b) the bottom of the atmosphere (BOA) represented as a function of the aerosol optical thickness (AOT) for each of the major periods, retrieved from AERONET.

In parallel to optical properties observations, the local 1-D (clear-sky) direct radiative effect (DRE) in the shortwave (SW) spectral region has been estimated using AERONET/PHOTONS retrievals (García et al., 2008) for each identified period. DRE is calculated here at two different atmospheric levels: at the surface (bottom of the atmosphere, BOA) and at the top of the atmosphere (TOA). Figure 15b indicates the SW DRE at BOA for different AOD and different solar angles observed during the experiment. The estimated values show significant variability with instantaneous DRE between -5 and $-40 \mathrm{~W} \mathrm{~m}^{-2}$, depending on the aerosol regimes. Figure 15a and b) indicates that PMA period is characterised by moderate TOA DRE (mean of $-8 \pm 3 \mathrm{~W} \mathrm{~m}^{-2}$ ) and BOA DRE (mean of $-11 \pm 4 \mathrm{~W} \mathrm{~m}^{-2}$ ). Such estimates at Ersa station are found to be consistent with direct SW effects of sea salt documented by Lundgren et al. (2013), who used the COSMO-ART model over the Mediterranean Basin and reported a SW DRE from -5 to $-10 \mathrm{~W} \mathrm{~m}^{-2}$ at the surface and an AOD between 0.1 and 0.2 (at $550 \mathrm{~nm}$ ).

The highest values of BOA DRE correspond to the highest AOD observed during dust event. For this specific event, values with peak maxima of $-43 \mathrm{~W} \mathrm{~m}^{-2}$ are in the same range of magnitude of values reported for mineral dust aerosols over the Mediterranean Basin by Di Biagio et al. (2010). Intermediate BOA DRE are calculated under polluted and biomass burning influence (from 5-12 July), and range from -13 to $-38 \mathrm{~W} \mathrm{~m}^{-2}$. Such values are classically derived over the western Mediterranean for polluted particles (Roger et al., 2006).

In addition, the calculated SW DRE at TOA is reported in Fig. 15a, showing negative effects in all conditions due to the moderate absorbing ability of aerosols associated with a low surface albedo at Ersa (Nicolas et al., 2017) and leading to cooling at TOA. It should be noted that the DRE of aerosols in the longwave (LW) spectral range, which can counterbalance a part of the SW cooling at TOA, is not estimated here. Contrary to the LW DRE of mineral dust exerted near dust sources, this effect is generally lower than SW DRE during the transport of mineral dust over the Mediterranean Basin (Nabat et al., 2015). In the same way as at the surface, Fig. 15b indicates that higher TOA DRE occur during the mineral dust event, with values as large as -20 to $-25 \mathrm{~W} \mathrm{~m}^{-2}$, but due to the spread of the values during the episode, the mean value of TOA DRE is in the same range as for BBP period. Finally, we report logically intermediate TOA DRE (mean of $-15 \pm 4 \mathrm{~W} \mathrm{~m}^{-2}$ ) between 5 and 12 July, when Ersa station is affected by pollution and smoke aerosols.

To conclude, PMA SW DRE at TOA and BOA is 2 or 3 times lower than what we encounter during events like dust outbreaks and biomass burning, which occur principally in spring and summer. However, the influence of marine aerosols is permanent, depending particularly on wind speed.

\section{Conclusion}

The ChArMEx-ADRIMED campaign that took place in summer 2013 in the western and central Mediterranean Basin has served to characterise the aerosol optical, physical and chemical properties, to quantify their direct radiative effect and study their implications on the regional climate (Mallet et al., 2016). One of the ground-based instrumented sites was based in Ersa, Cap Corse and allowed the study of different aerosol types, particularly the properties and relative impacts of PMA compared to other aerosol types present in the western Mediterranean Basin.

Using FLEXPART back-trajectory simulations and in situ optical, physical and chemical measurements, we show that 
Ersa was impacted by air masses coming from different source regions and bringing different aerosol types. Three main periods have been identified to characterise the relative impacts of the major aerosol types and, in particular, a period (22-26 June) when the Ersa site is mainly affected by PMA. During this period, the Ersa station was influenced by a westerly wind bringing air masses from the Gulf of Lion, the Mediterranean coasts of France and Spain and the Bay of Biscay. During this specific event, the concentration of PMA was relatively high, reaching $6.5 \mu \mathrm{g} \mathrm{m}^{-3}$, which represents $40 \%$ of the total $\mathrm{PM}_{10}$ mass concentration. Here, an original data set, obtained from ATOFMS and PILS-IC instruments has been used to study the ageing of PMA. By comparing the two instruments, we found that the majority of the time PMA had already undergone chemical reactions and so were not freshly emitted near Cap Corse, but rather advected from long-range transport. In particular, during the PMA period, based on FLEXPART simulations and local wind speed measurements, we distinguished the origin of fresh and aged PMA composing the mixing of PMA observed in the Ersa station. We found that fresh PMAs were emitted near the station under high wind speed conditions while aged PMAs were most probably originating from the Gulf of Lion (Mediterranean) and not from the Bay of Biscay (North Atlantic Ocean).

These two original instruments display similar results regarding PMA ageing, and detect different short periods (of few hours duration) of mostly aged or mostly fresh PMA dominance that we used for our analysis.

No significant distinction was found between the number size distribution of fresh and aged supermicron PMA, and so the size distribution was fitted regardless of the ageing of these aerosols. The log-normal modes (four modes with diameters of $0.04,0.13,1.2$ and $5.4 \mu \mathrm{m}$ ) found for these PMA were in agreement with previous measurement made by Ovadnevaite et al. (2014) and Schwier et al. (2015). The PMA episode was also influenced by fine particles, denoted by the high number concentration of fine particle and by an Ångström exponent varying between 0.4 and 2. In parallel, low AOD (mean of 0.11 at $500 \mathrm{~nm}$ ) and SSA (at $440 \mathrm{~nm}$ ) close to unity also measured at Ersa are typical of the PMA influence. The SW DRF showed the lowest values at the surface compared to other aerosol regimes with a mean of $-11 \pm 4 \mathrm{~W} \mathrm{~m}^{-2}$. At the top of the atmosphere (TOA), the lowest values were also observed during the PMA event (mean of $-8 \pm 3 \mathrm{~W} \mathrm{~m}^{-2}$ ).

The aerosol properties obtained during this PMA event were compared to two other periods encountered during the field campaign (dust and BBP). The first period corresponds to a dust outbreak of moderate intensity (16-20 June; dust), and the last period (5-12 July) is characterised by biomass burning that originated in Ukraine and mixed with pollution in southern Europe (BBP). In terms of physical and chemical properties, our results display large variability in the number and volume size distribution as well as mass concentra- tions between the different events. The volume size distribution analyses reveal that the BBP event is dominated by a fine mode of particles with a modal diameter of $320 \mathrm{~nm}$, while the PMA period is dominated by a coarse mode with a modal diameter of $1.64 \mu \mathrm{m}$. Finally, dust aerosols observed at Ersa are characterised by a modal diameter of $2.4 \mu \mathrm{m}$, which is found to be consistent with aircraft in situ observations within dust plumes in the free troposphere during the airborne portion of the ChArMEx-ADRIMED experiment (Denjean et al., 2016).

Concerning the optical properties, our results indicate that the dust event is characterised by a moderate AOD with a mean of $0.16 \pm 0.08$ and highest values reaching 0.30 (at $500 \mathrm{~nm}$ ) associated with a mean AE of 1.4 (calculated between 440 and $870 \mathrm{~nm}$ ). SSA during the dust episode (0.97 at $440 \mathrm{~nm}$ ) is found to be high, revealing mostly scattering dust aerosols in this case.

The most intense optical signature clearly occurs at the end of the campaign during the BBP episode. For this specific period, a significant scattering coefficient estimated at the surface (mean of $54 \mathrm{Mm}^{-1}$ at $550 \mathrm{~nm}$, together with moderate AOD $(0.23 \pm 0.07$ at $500 \mathrm{~nm})$ and elevated spectral dependence are observed.

In terms of SW DRF, our results showed the highest (lowest) contribution to surface effects during the dust (PMA) event with $-21 \pm 11 \mathrm{~W} \mathrm{~m}^{-2}\left(-11 \pm 4 \mathrm{~W} \mathrm{~m}^{-2}\right)$, with intermediate values $\left(-23 \pm 6 \mathrm{~W} \mathrm{~m}^{-2}\right)$ observed during the BBP episode. All derived SW DRF at the surface for the three aerosol types are similar to previous studies in the western Mediterranean Basin. Similar results are obtained for the top of the atmosphere (TOA) effect, with the highest values occurring during the dust outbreak $\left(-14 \pm 6 \mathrm{~W} \mathrm{~m}^{-2}\right)$ and BBP period $\left(-15 \pm 4 \mathrm{~W} \mathrm{~m}^{-2}\right)$, while the lowest values were observed during the PMA event $\left(-8 \pm 3 \mathrm{~W} \mathrm{~m}^{-2}\right)$. Even though the magnitude of PMA DRF is relatively small compared to dust and BBP DRF, its impact is permanent due to the persistency of PMA in the marine atmosphere.

Data availability. AERONET/PHOTONS data are available on the website https://aeronet.gsfc.nasa.gov/. The data (FLEXPART back trajectories, aerosol chemical, physical and optical properties) used in the paper are part of the ChArMEx-ADRIMED project and are available from the ChArMEx database by request (http://mistrals. sedoo.fr/).

Author contributions. PILS-IC, ACSM, TEOM PM10 and TEOM PM1 data were provided by J. Sciare; ATOFMS data were provided by J. Arndt and J. Wenger; SMPS, OPS, CPC, Nephelometer and meteorological data were provided by Météo-France. M. Claeys prepared the manuscript with contributions from all co-authors.

Competing interests. The authors declare that they have no conflict of interest. 
Acknowledgements. This research was supported by Direction Générale de l'Armement (DGA) and Météo-France. This research has received funding from the French National Research Agency (ANR) project ADRIMED (contract ANR-11-BS56-0006). This work is part of the ChArMEx project supported by ADEME, CEA, CNRS-INSU and Météo-France through the multidisciplinary programme MISTRALS (Mediterranean Integrated Studies aT Regional And Local Scales). The station at Ersa was partly supported by the CORSiCA project funded by the Collectivité Territoriale de Corse through the Fonds Européen de Développement Régional of the European Operational Program 2007-2013 and the Contrat de Plan Etat-Région. We acknowledge the AERONET/PHOTONS sun photometer networks and the PI of the Ersa station and their staff for their work to produce the data set used in this study. Contributions by Thierry Bourrianne and help from Cyrielle Denjean are gratefully acknowledged. We gratefully acknowledge the two anonymous reviewers whose comments helped us to improve this manuscript. Thanks to Laurent Gomez without whom this study would have never taken place.

Edited by: E. Gerasopoulos

Reviewed by: two anonymous referees

\section{References}

Anderson, T. L. and Ogren, J. A.: Determining aerosol radiative properties using the TSI 3563 integrating nephelometer, Aerosol Sci. Technol., 29, 57-69, 1998.

Andreae, M. and Rosenfeld, D.: Aerosol-cloud-precipitation interactions. Part 1. The nature and sources of cloud-active aerosols, Earth-Sci. Rev., 89, 13-41, https://doi.org/10.1016/j.earscirev.2008.03.001, 2008.

Andreae, M. O.: Aerosols before pollution, Science, 315, 50-51, 2007

Arndt, J., Sciare, J., Mallet, M., Roberts, G. C., Marchand, N., Sartelet, K., Sellegri, K., Dulac, F., Healy, R. M., and Wenger, J. C.: Sources and mixing state of summertime background aerosol in the north-western Mediterranean basin, Atmos. Chem. Phys., 17, 6975-7001, https://doi.org/10.5194/acp17-6975-2017, 2017

Bardouki, H., Liakakou, H., Economou, C., Sciare, J., Smolík, J., Ždímal, V., Eleftheriadis, K., Lazaridis, M., Dye, C., and Mihalopoulos, N.: Chemical composition of size-resolved atmospheric aerosols in the eastern Mediterranean during summer and winter, Atmos. Environ., 37, 195-208, https://doi.org/10.1016/S1352-2310(02)00859-2, 2003.

Bellouin, N., Jones, A., Haywood, J., and Christopher, S. A.: Updated estimate of aerosol direct radiative forcing from satellite observations and comparison against the Hadley Centre climate model, J. Geophys. Res.-Atmos., 113, D10205, https://doi.org/10.1029/2007JD009385, 2008.

Bressan, D. and Lepple, F.: Dependence of sea-salt aerosol concentration on various environmental parameters, Advances in chemistry series, 75-98, 1985.

Bressi, M., Sciare, J., Ghersi, V., Bonnaire, N., Nicolas, J. B., Petit, J.-E., Moukhtar, S., Rosso, A., Mihalopoulos, N., and Féron, A.: A one-year comprehensive chemical characterisation of fine aerosol $\left(\mathrm{PM}_{2.5}\right)$ at urban, suburban and rural background sites in the region of Paris (France), Atmos. Chem. Phys., 13, 78257844, https://doi.org/10.5194/acp-13-7825-2013, 2013.

Brewer, P. G.: Minor elements in sea water, Chemical oceanography, 1, 415-496, 1975.

Carslaw, D. C. and Ropkins, K.: Openair - an R package for air quality data analysis, Environ. Modell. Softw., 27, 52-61, 2012.

Chabas, a. and Lefèvre, R. a.: Chemistry and microscopy of atmospheric particulates at Delos (Cyclades- Greece), Atmos. Environ., 34, 225-238, https://doi.org/10.1016/S13522310(99)00255-1, 2000.

Clegg, S. L. and Brimblecombe, P.: Potential degassing of hydrogen chloride from acidified sodium chloride droplets, Atmos. Environ., 19, 465-470, https://doi.org/10.1016/0004-6981(85)901672, 1985 .

Crenn, V., Sciare, J., Croteau, P. L., Verlhac, S., Fröhlich, R., Belis, C. A., Aas, W., Äijälä, M., Alastuey, A., Artiñano, B., Baisnée, D., Bonnaire, N., Bressi, M., Canagaratna, M., Canonaco, F., Carbone, C., Cavalli, F., Coz, E., Cubison, M. J., Esser-Gietl, J. K., Green, D. C., Gros, V., Heikkinen, L., Herrmann, H., Lunder, C., Minguillón, M. C., Mocnik, G., O’Dowd, C. D., Ovadnevaite, J., Petit, J.-E., Petralia, E., Poulain, L., Priestman, M., Riffault, V., Ripoll, A., Sarda-Estève, R., Slowik, J. G., Setyan, A., Wiedensohler, A., Baltensperger, U., Prévôt, A. S. H., Jayne, J. T., and Favez, O.: ACTRIS ACSM intercomparison - Part 1: Reproducibility of concentration and fragment results from 13 individual Quadrupole Aerosol Chemical Speciation Monitors (Q-ACSM) and consistency with co-located instruments, Atmos. Meas. Tech., 8, 5063-5087, https://doi.org/10.5194/amt-8-50632015, 2015.

Crippa, M., DeCarlo, P. F., Slowik, J. G., Mohr, C., Heringa, M. F., Chirico, R., Poulain, L., Freutel, F., Sciare, J., Cozic, J., Di Marco, C. F., Elsasser, M., Nicolas, J. B., Marchand, N., Abidi, E., Wiedensohler, A., Drewnick, F., Schneider, J., Borrmann, S., Nemitz, E., Zimmermann, R., Jaffrezo, J.-L., Prévôt, A. S. H., and Baltensperger, U.: Wintertime aerosol chemical composition and source apportionment of the organic fraction in the metropolitan area of Paris, Atmos. Chem. Phys., 13, 961-981, https://doi.org/10.5194/acp-13-961-2013, 2013.

Cros, B., Durand, P., Cachier, H., Drobinski, P., Frejafon, E., Kottmeier, C., Perros, P., Peuch, V.-H., Ponche, J.-L., Robin, D., Sald, F., Toupance, G., and Wortham, H.: The ESCOMPTE program: an overview, Atmos. Res., 69, 241-279, 2004.

D O'Dowd, C. and De Leeuw, G.: Marine aerosol production: a review of the current knowledge, Philosophical Transactions of the Royal Society of London A: Mathematical, Phys. Eng. Sci., 365, 1753-1774, 2007.

Dall'Osto, M., Beddows, D., Kinnersley, R. P., Harrison, R. M., Donovan, R. J., and Heal, M. R.: Characterization of individual airborne particles by using aerosol time-of-flight mass spectrometry at Mace Head, Ireland, J. Geophys. Res.-Atmos., 109, D21302, https://doi.org/10.1029/2004JD004747, 2004.

Denjean, C., Formenti, P., Desboeufs, K., Chevaillier, S., Triquet, S., Maillé, M., Cazaunau, M., Laurent, B., Mayol-Bracero, O. L., Vallejo, P., et al.: Size distribution and optical properties of African mineral dust after intercontinental transport, J. Geophys. Res.-Atmos., 121, 7117-7138, 2016.

Di Biagio, C., di Sarra, A., and Meloni, D.: Large atmospheric shortwave radiative forcing by Mediterranean aerosols derived from simultaneous ground-based and spaceborne ob- 
servations and dependence on the aerosol type and single scattering albedo, J. Geophys. Res.-Atmos., 115, D10209, https://doi.org/10.1029/2009JD012697, 2010.

Di Iorio, T., di Sarra, A., Sferlazzo, D., Cacciani, M., Meloni, D., Monteleone, F., Fua, D., and Fiocco, G.: Seasonal evolution of the tropospheric aerosol vertical profile in the central Mediterranean and role of desert dust, J. Geophys. Res.-Atmos., 114, D02201, https://doi.org/10.1029/2008JD010593, 2009.

Di Sarra, A., Di Biagio, C., Meloni, D., Monteleone, F., Pace, G., Pugnaghi, S., and Sferlazzo, D.: Shortwave and longwave radiative effects of the intense Saharan dust event of 25-26 March 2010 at Lampedusa (Mediterranean Sea), J. Geophys. Res.Atmos., 116, D23209, https://doi.org/10.1029/2011JD016238, 2011.

Dubovik, O. and King, M. D.: A flexible inversion algorithm for retrieval of aerosol optical properties from Sun and sky radiance measurements, J. Geophys. Res., 105, 20673, https://doi.org/10.1029/2000JD900282, 2000.

Dubovik, O., Holben, B., Eck, T. F., Smirnov, A., Kaufman, Y. J., King, M. D., Tanré, D., and Slutsker, I.: Variability of absorption and optical properties of key aerosol types observed in worldwide locations, J. Atmos. Sci., 59, 590-608, 2002a.

Dubovik, O., Holben, B., Lapyonok, T., Sinyuk, A., Mishchenko, M., Yang, P., and Slutsker, I.: Non-spherical aerosol retrieval method employing light scattering by spheroids, Geophys. Res. Lett., 29, 54-1-54-4, https://doi.org/10.1029/2001GL014506, 2002b.

Dulac, F. and Chazette, P.: Airborne study of a multi-layer aerosol structure in the eastern Mediterranean observed with the airborne polarized lidar ALEX during a STAAARTE campaign (7 June 1997), Atmos. Chem. Phys., 3, 1817-1831, https://doi.org/10.5194/acp-3-1817-2003, 2003.

Emanuel, K. A. and Živkovic-Rothman, M.: Development and evaluation of a convection scheme for use in climate models, J. Atmos. Sci., 56, 1766-1782, 1999.

Fomba, K. W., Müller, K., van Pinxteren, D., Poulain, L., van Pinxteren, M., and Herrmann, H.: Long-term chemical characterization of tropical and marine aerosols at the Cape Verde Atmospheric Observatory (CVAO) from 2007 to 2011, Atmos. Chem. Phys., 14, 8883-8904, https://doi.org/10.5194/acp-148883-2014, 2014.

Forster, P., Ramaswamy, V., Artaxo, P., Berntsen, T., Betts, R., Fahey, D. W., Haywood, J., Lean, J., Lowe, D. C., Myhre, G., Nganga, J., Prinn, R., Raga, G., Schulz, M., and Van Dorland, R.: Changes in atmospheric constituents and in radiative forcing, chap. 2, in: Climate Change 2007. The Physical Science Basis, Cambridge University Press, Cambridge, UK, 2007.

Fotiadi, A., Hatzianastassiou, N., Drakakis, E., Matsoukas, C., Pavlakis, K. G., Hatzidimitriou, D., Gerasopoulos, E., Mihalopoulos, N., and Vardavas, I.: Aerosol physical and optical properties in the Eastern Mediterranean Basin, Crete, from Aerosol Robotic Network data, Atmos. Chem. Phys., 6, 53995413, https://doi.org/10.5194/acp-6-5399-2006, 2006.

Fröhlich, R., Crenn, V., Setyan, A., Belis, C. A., Canonaco, F., Favez, O., Riffault, V., Slowik, J. G., Aas, W., Aijälä, M., Alastuey, A., Artiñano, B., Bonnaire, N., Bozzetti, C., Bressi, M., Carbone, C., Coz, E., Croteau, P. L., Cubison, M. J., EsserGietl, J. K., Green, D. C., Gros, V., Heikkinen, L., Herrmann, H., Jayne, J. T., Lunder, C. R., Minguillón, M. C., Mocnik, G.,
O’Dowd, C. D., Ovadnevaite, J., Petralia, E., Poulain, L., Priestman, M., Ripoll, A., Sarda-Estève, R., Wiedensohler, A., Baltensperger, U., Sciare, J., and Prévôt, A. S. H.: ACTRIS ACSM intercomparison - Part 2: Intercomparison of ME-2 organic source apportionment results from 15 individual, co-located aerosol mass spectrometers, Atmos. Meas. Tech., 8, 2555-2576, https://doi.org/10.5194/amt-8-2555-2015, 2015.

Gantt, B. and Meskhidze, N.: The physical and chemical characteristics of marine primary organic aerosol: a review, Atmos. Chem. Phys., 13, 3979-3996, https://doi.org/10.5194/acp13-3979-2013, 2013.

García, O., Díaz, A., Expósito, F., Diaz, J., Dubovik, O., Dubuisson, P., Roger, J.-C., Eck, T., Sinyuk, A., Derimian, Y., Dutton, E. G., Schafer, J. S., Holben, B. N., and García, C. A.: Validation of AERONET estimates of atmospheric solar fluxes and aerosol radiative forcing by ground-based broadband measurements, J. Geophys. Res.-Atmos., 113, D21207, https://doi.org/10.1029/2008JD010211, 2008.

García, O. E., Díaz, J. P., Expósito, F. J., Dîaz, A. M., Dubovik, O., Derimian, Y., Dubuisson, P., and Roger, J.-C.: Shortwave radiative forcing and efficiency of key aerosol types using AERONET data, Atmos. Chem. Phys., 12, 5129-5145, https://doi.org/10.5194/acp-12-5129-2012, 2012.

Gard, E., Mayer, J. E., Morrical, B. D., Dienes, T., Fergenson, D. P., and Prather, K. A.: Real-time analysis of individual atmospheric aerosol particles: Design and performance of a portable ATOFMS, Anal. Chem., 69, 4083-4091, 1997.

Gard, E. E., Kleeman, M. J., Gross, D. S., Hughes, L. S., Allen, J. O., Morrical, B. D., Fergenson, D. P., Dienes, T., Gälli, M. E., Johnson, R. J., Cass, G. R., and Prather, K. A.: Direct observation of heterogeneous chemistry in the atmosphere, Science, 279 , 1184-1187, 1998.

Gómez-Amo, J., Pinti, V., Di Iorio, T., Di Sarra, A., Meloni, D., Becagli, S., Bellantone, V., Cacciani, M., Fuà, D., and Perrone, M.: The June 2007 Saharan dust event in the central Mediterranean: Observations and radiative effects in marine, urban, and sub-urban environments, Atmos. Environ., 45, 5385-5393, 2011.

Guerrero-Rascado, J. L., Olmo, F. J., Avilés-Rodríguez, I., NavasGuzmán, F., Pérez-Ramírez, D., Lyamani, H., and Alados Arboledas, L.: Extreme Saharan dust event over the southern Iberian Peninsula in september 2007: active and passive remote sensing from surface and satellite, Atmos. Chem. Phys., 9, 84538469, https://doi.org/10.5194/acp-9-8453-2009, 2009.

Guyon, P., Frank, G. P., Welling, M., Chand, D., Artaxo, P., Rizzo, L., Nishioka, G., Kolle, O., Fritsch, H., Silva Dias, M. A. F., Gatti, L. V., Cordova, A. M., and Andreae, M. O.: Airborne measurements of trace gas and aerosol particle emissions from biomass burning in Amazonia, Atmos. Chem. Phys., 5, 29893002, https://doi.org/10.5194/acp-5-2989-2005, 2005.

Hamonou, E., Chazette, P., Balis, D., Dulac, F., Schneider, X., Galani, E., Ancellet, G., and Papayannis, A.: Characterization of the vertical structure of Saharan dust export, J. Geophys. Res., 104, 22-257, 1999.

Healy, R. M., Hellebust, S., Kourtchev, I., Allanic, A., O’Connor, I. P., Bell, J. M., Healy, D. A., Sodeau, J. R., and Wenger, J. C.: Source apportionment of $\mathrm{PM}_{2.5}$ in Cork Harbour, Ireland using a combination of single particle mass spectrometry and quantitative semi-continuous measurements, Atmos. Chem. Phys., 10, 9593-9613, https://doi.org/10.5194/acp-10-9593-2010, 2010. 
Healy, R. M., Sciare, J., Poulain, L., Crippa, M., Wiedensohler, A., Prévôt, A. S. H., Baltensperger, U., Sarda-Estève, R., McGuire, M. L., Jeong, C.-H., McGillicuddy, E., O'Connor, I. P., Sodeau, J. R., Evans, G. J., and Wenger, J. C.: Quantitative determination of carbonaceous particle mixing state in Paris using single-particle mass spectrometer and aerosol mass spectrometer measurements, Atmos. Chem. Phys., 13, 9479-9496, https://doi.org/10.5194/acp-13-9479-2013, 2013.

Jayne, J. T., Leard, D. C., Zhang, X., Davidovits, P., Smith, K. A., Kolb, C. E., and Worsnop, D. R.: Development of an aerosol mass spectrometer for size and composition analysis of submicron particles, Aerosol Sci. Technol., 33, 49-70, 2000.

Kaufman, Y. J. and Koren, I.: Smoke and pollution aerosol effect on cloud cover, Science, 313, 655-658, 2006.

Kaufman, Y. J., Smirnov, A., Holben, B. N., and Dubovik, O.: Baseline maritime aerosol: methodology to derive the optical thickness and scattering properties, Geophys. Res. Lett., 28, 32513254, 2001.

Khain, A.: Notes on state-of-the-art investigations of aerosol effects on precipitation: a critical review, Environ. Res. Lett., 4, 015004, https://doi.org/10.1088/1748-9326/4/1/015004, 2009.

Koçak, M., Kubilay, N., and Mihalopoulos, N.: Ionic composition of lower tropospheric aerosols at a Northeastern Mediterranean site: Implications regarding sources and long-range transport, Atmos. Environ., 38, 2067-2077, https://doi.org/10.1016/j.atmosenv.2004.01.030, 2004.

Koulouri, E., Saarikoski, S., Theodosi, C., Markaki, Z., Gerasopoulos, E., Kouvarakis, G., Mäkelä, T., Hillamo, R., and Mihalopoulos, N.: Chemical composition and sources of fine and coarse aerosol particles in the Eastern Mediterranean, Atmos. Environ., 42, 6542-6550, https://doi.org/10.1016/j.atmosenv.2008.04.010, 2008.

Lelieveld, J., Hadjinicolaou, P., Kostopoulou, E., Chenoweth, J., El Maayar, M., Giannakopoulos, C., Hannides, C., Lange, M., Tanarhte, M., Tyrlis, E., and Xoplaki, E.: Climate change and impacts in the Eastern Mediterranean and the Middle East, Climatic Change, 114, 667-687, 2012.

Lewis, E. R. and Schwartz, S. E.: Sea salt aerosol production: mechanisms, methods, measurements, and models-A critical review, American geophysical union, 2004.

Li, Z., Niu, F., Fan, J., Liu, Y., Rosenfeld, D., and Ding, Y.: Longterm impacts of aerosols on the vertical development of clouds and precipitation, Nat. Geosci., 4, 888-894, 2011.

Lundgren, K., Vogel, B., Vogel, H., and Kottmeier, C.: Direct radiative effects of sea salt for the Mediterranean region under conditions of low to moderate wind speeds, J. Geophys. Res.-Atmos., 118, 1906-1923, https://doi.org/10.1029/2012JD018629, 2013.

Mallet, M., Dubovik, O., Nabat, P., Dulac, F., Kahn, R., Sciare, J., Paronis, D., and Léon, J. F.: Absorption properties of Mediterranean aerosols obtained from multi-year ground-based remote sensing observations, Atmos. Chem. Phys., 13, 9195-9210, https://doi.org/10.5194/acp-13-9195-2013, 2013.

Mallet, M., Dulac, F., Formenti, P., Nabat, P., Sciare, J., Roberts, G., Pelon, J., Ancellet, G., Tanré, D., Parol, F., Denjean, C., Brogniez, G., di Sarra, A., Alados-Arboledas, L., Arndt, J., Auriol, F., Blarel, L., Bourrianne, T., Chazette, P., Chevaillier, S., Claeys, M., D’Anna, B., Derimian, Y., Desboeufs, K., Di Iorio, T., Doussin, J.-F., Durand, P., Féron, A., Freney, E., Gaimoz, C., Goloub, P., Gómez-Amo, J. L., Granados-Muñoz, M. J., Grand,
N., Hamonou, E., Jankowiak, I., Jeannot, M., Léon, J.-F., Maillé, M., Mailler, S., Meloni, D., Menut, L., Momboisse, G., Nicolas, J., Podvin, T., Pont, V., Rea, G., Renard, J.-B., Roblou, L., Schepanski, K., Schwarzenboeck, A., Sellegri, K., Sicard, M., Solmon, F., Somot, S., Torres, B., Totems, J., Triquet, S., Verdier, N., Verwaerde, C., Waquet, F., Wenger, J., and Zapf, P.: Overview of the Chemistry-Aerosol Mediterranean Experiment/Aerosol Direct Radiative Forcing on the Mediterranean Climate (ChArMEx/ADRIMED) summer 2013 campaign, Atmos. Chem. Phys., 16, 455-504, https://doi.org/10.5194/acp-16455-2016, 2016.

Marks, R.: Preliminary investigations on the influence of rain on the production, concentration, and vertical distribution of sea salt aerosol, J. Geophys. Res.-Oceans, 95, 22299-22304, 1990.

Meloni, D., Di Sarra, A., Di Iorio, T., and Fiocco, G.: Direct radiative forcing of Saharan dust in the Mediterranean from measurements at Lampedusa Island and MISR spaceborne observations, J. Geophys. Res.-Atmos., 109, D08206, https://doi.org/10.1029/2003JD003960, 2004.

Mihalopoulos, N., Stephanou, E., Kanakidou, M., Pilitsidis, S., and Bousquet, P.: Tropospheric aerosol ionic composition in the Eastern Mediterranean region, Wiley Online Library, https://doi.org/10.1034/j.1600-0889.49.issue3.7.x, 1997.

Mishra, A. K., Klingmueller, K., Fredj, E., Lelieveld, J., Rudich, Y., and Koren, I.: Radiative signature of absorbing aerosol over the eastern Mediterranean basin, Atmos. Chem. Phys., 14, 72137231, https://doi.org/10.5194/acp-14-7213-2014, 2014.

Mona, L., Amodeo, A., Pandolfi, M., and Pappalardo, G.: Saharan dust intrusions in the Mediterranean area: Three years of Raman lidar measurements, J. Geophys. Res.-Atmos., 111, D16203, https://doi.org/10.1029/2005JD006569, 2006.

Mulcahy, J. P., O’Dowd, C. D., Jennings, S. G., and Ceburnis, D.: Significant enhancement of aerosol optical depth in marine air under high wind conditions, Geophys. Res. Lett., 35, 1-4, https://doi.org/10.1029/2008GL034303, 2008.

Nabat, P., Somot, S., Mallet, M., Michou, M., Sevault, F., Driouech, F., Meloni, D., di Sarra, A., Di Biagio, C., Formenti, P., Sicard, M., Léon, J.-F., and Bouin, M.-N.: Dust aerosol radiative effects during summer 2012 simulated with a coupled regional aerosol-atmosphere-ocean model over the Mediterranean, Atmos. Chem. Phys., 15, 3303-3326, https://doi.org/10.5194/acp15-3303-2015, 2015.

Ng, N. L., Herndon, S. C., Trimborn, A., Canagaratna, M. R., Croteau, P., Onasch, T. B., Sueper, D., Worsnop, D. R., Zhang, Q., Sun, Y., and Jayne, J. T.: An Aerosol Chemical Speciation Monitor (ACSM) for routine monitoring of the composition and mass concentrations of ambient aerosol, Aerosol Sci. Technol., 45, 780-794, 2011.

Nicolas, J.: Caractérisation physico-chimique de l'aérosol troposphérique en Méditerranée: sources et devenir, $\mathrm{PhD}$ thesis, Univ. Versailles Saint-Quentin, 121 pp., 2013.

Noble, C. A. and Prather, K. A.: Real-time single particle monitoring of a relative increase in marine aerosol concentration during winter rainstorms, Geophys. Res. Lett., 24, 2753-2756, 1997.

O’Dowd, C. D., Facchini, M. C., Cavalli, F., Ceburnis, D., Mircea, M., Decesari, S., Fuzzi, S., Yoon, Y. J., and Putaud, J.-P.: Biogenically driven organic contribution to marine aerosol, Nature, 431, 676-680, 2004. 
Orsini, D. A., Ma, Y., Sullivan, A., Sierau, B., Baumann, K., and Weber, R. J.: Refinements to the particle-into-liquid sampler (PILS) for ground and airborne measurements of water soluble aerosol composition, Atmos. Environ., 37, 1243-1259, 2003.

Ovadnevaite, J., Manders, A., de Leeuw, G., Ceburnis, D., Monahan, C., Partanen, A.-I., Korhonen, H., and O'Dowd, C. D.: A sea spray aerosol flux parameterization encapsulating wave state, Atmos. Chem. Phys., 14, 1837-1852, https://doi.org/10.5194/acp14-1837-2014, 2014.

Pace, G., di Sarra, A., Meloni, D., Piacentino, S., and Chamard, P.: Aerosol optical properties at Lampedusa (Central Mediterranean) 1. Influence of transport and identification of different aerosol types, Atmos. Chem. Phys., 6, 697-713, https://doi.org/10.5194/acp-6-697-2006, 2006.

Pey, J., Querol, X., and Alastuey, A.: Variations of levels and composition of PM10 and PM2.5 at an insular site in the Western Mediterranean, Atmos. Res., 94, 285-299, https://doi.org/10.1016/j.atmosres.2009.06.006, 2009.

Querol, X., Alastuey, A., Pey, J., Cusack, M., Pérez, N., Mihalopoulos, N., Theodosi, C., Gerasopoulos, E., Kubilay, N., and Koçak, M.: Variability in regional background aerosols within the Mediterranean, Atmos. Chem. Phys., 9, 4575-4591, https://doi.org/10.5194/acp-9-4575-2009, 2009.

Quinn, P., Bates, T., Coffman, D., Miller, T., Johnson, J., Covert, D., Putaud, J.-P., Neusüß, C., and Novakov, T.: A comparison of aerosol chemical and optical properties from the 1st and 2nd Aerosol Characterization Experiments, Tellus B, 52, 239-257, 2000.

Quinn, P. K. and Bates, T. S.: Regional aerosol properties: Comparisons of boundary layer measurements from ACE 1, ACE 2, Aerosols99, INDOEX, ACE Asia, TARFOX, and NEAQS, J. Geophys. Res.-Atmos., 110, D14202, https://doi.org/10.1029/2004JD004755, 2005.

Reid, J. S., Koppmann, R., Eck, T. F., and Eleuterio, D. P.: A review of biomass burning emissions part II: intensive physical properties of biomass burning particles, Atmos. Chem. Phys., 5, 799825, https://doi.org/10.5194/acp-5-799-2005, 2005.

Ripoll, A., Minguillón, M. C., Pey, J., Pérez, N., Querol, X., and Alastuey, A.: Joint analysis of continental and regional background environments in the western Mediterranean: PM1 and PM10 concentrations and composition, Atmos. Chem. Phys., 15, 1129-1145, https://doi.org/10.5194/acp-15-1129-2015, 2015.

Roger, J.-C., Mallet, M., Dubuisson, P., Cachier, H., Vermote, E., Dubovik, O., and Despiau, S.: A synergetic approach for estimating the local direct aerosol forcing: Application to an urban zone during the Expérience sur Site pour Contraindre les Modèles de Pollution et de Transport d'Emission (ESCOMPTE) experiment, J. Geophys. Res.-Atmos., 111, D13208, https://doi.org/10.1029/2005JD006361, 2006.

Salameh, T., Drobinski, P., Menut, L., Bessagnet, B., Flamant, C., Hodzic, A., and Vautard, R.: Aerosol distribution over the western Mediterranean basin during a Tramontane/Mistral event, Ann. Geophys., 25, 2271-2291, https://doi.org/10.5194/angeo25-2271-2007, 2007.

Schwier, A. N., Rose, C., Asmi, E., Ebling, A. M., Landing, W. M., Marro, S., Pedrotti, M.-L., Sallon, A., Iuculano, F., Agusti, S., Tsiola, A., Pitta, P., Louis, J., Guieu, C., Gazeau, F., and Sellegri, K.: Primary marine aerosol emissions from the Mediterranean Sea during pre-bloom and oligotrophic conditions: cor- relations to seawater chlorophyll $a$ from a mesocosm study, Atmos. Chem. Phys., 15, 7961-7976, https://doi.org/10.5194/acp15-7961-2015, 2015.

Schwier, A. N., Sellegri, K., Mas, S., Charrière, B., Pey, J., Rose, C., Terminé-Roussel, B., Jaffrezo, J.-L., Parin, D., Picard, D., Ribeiro, M., Roberts, G., Sempéré, R., Marchand, N., and D'Anna, B.: Primary marine aerosol physical and chemical emissions during a nutriment enrichment experiment in mesocosms in the Mediterranean Sea, Atmos. Chem. Phys. Discuss., https://doi.org/10.5194/acp-2017-320, in review, 2017.

Sciare, J., Bardouki, H., Moulin, C., and Mihalopoulos, N.: Aerosol sources and their contribution to the chemical composition of aerosols in the Eastern Mediterranean Sea during summertime, Atmos. Chem. Phys., 3, 291-302, https://doi.org/10.5194/acp-3291-2003, 2003.

Sciare, J., d'Argouges, O., Sarda-Estève, R., Gaimoz, C., Dolgorouky, C., Bonnaire, N., Favez, O., Bonsang, B., and Gros, V.: Large contribution of water-insoluble secondary organic aerosols in the region of Paris (France) during wintertime, J. Geophys. Res.-Atmos., 116, D22203, https://doi.org/10.1029/2011JD015756, 2011.

Seiki, T. and Nakajima, T.: Aerosol effects of the condensation process on a convective cloud simulation, J. Atmos. Sci., 71, 833853, 2014.

Sellegri, K., Gourdeau, J., Putaud, J.-P., and Despiau, S.: Chemical composition of marine aerosol in a Mediterranean coastal zone during the FETCH experiment, J. Geophys. Res., 106, 12023, https://doi.org/10.1029/2000JD900629, 2001.

Shinozuka, Y., Clarke, A. D., Howell, S. G., Kapustin, V. N., and Huebert, B. J.: Sea-salt vertical profiles over the Southern and tropical Pacific oceans: Microphysics, optical properties, spatial variability, and variations with wind speed, J. Geophys. Res.Atmos., 109, D24201, https://doi.org/10.1029/2004JD004975, 2004.

Smirnov, A., Villevalde, Y., O’Neill, N., Royer, A., and Tarussov, A.: Aerosol optical depth over the oceans: Analysis in terms of synoptic air mass types, J. Geophys. Res.-Atmos., 100, 16639 16650, 1995.

Smirnov, A., Holben, B. N., Dubovik, O., O’Neill, N. T., Eck, T. F., Westphal, D. L., Goroch, A. K., Pietras, C., and Slutsker, I.: Atmospheric Aerosol Optical Properties in the Persian Gulf, J. Atmos. Sci., 59, 620-634, https://doi.org/10.1175/15200469(2002)059<0620:AAOPIT>2.0.CO;2, 2002.

Stevens, B. and Feingold, G.: Untangling aerosol effects on clouds and precipitation in a buffered system, Nature, 461, 607-613, 2009.

Stohl, A. and Thomson, D. J.: A density correction for Lagrangian particle dispersion models, Bound.-Lay. Meteorol., 90, 155-167, 1999.

Stohl, A., Hittenberger, M., and Wotawa, G.: Validation of the Lagrangian particle dispersion model FLEXPART against largescale tracer experiment data, Atmos. Environ., 32, 4245-4264, 1998.

Stohl, A., Eckhardt, S., Forster, C., James, P., Spichtinger, N., and Seibert, P.: A replacement for simple back trajectory calculations in the interpretation of atmospheric trace substance measurements, Atmos. Environ., 36, 4635-4648, 2002.

Su, Y., Sipin, M. F., Furutani, H., and Prather, K. A.: Development and characterization of an aerosol time-of-flight mass spectrom- 
eter with increased detection efficiency, Anal. Chem., 76, 712$719,2004$.

Taylor, N. J. and Wu, J.: Simultaneous measurements of spray and sea salt, J. Geophys. Res.-Oceans, 97, 7355-7360, 1992.

Tsyro, S., Aas, W., Soares, J., Sofiev, M., Berge, H., and Spindler, G.: Modelling of sea salt concentrations over Europe: key uncertainties and comparison with observations, Atmos. Chem. Phys., 11, 10367-10388, https://doi.org/10.5194/acp-11-103672011, 2011.
Zhao, T. X.-P., Loeb, N. G., Laszlo, I., and Zhou, M.: Global component aerosol direct radiative effect at the top of atmosphere, Int. J. Remote Sens., 32, 633-655, 2011.

Zorn, S. R., Drewnick, F., Schott, M., Hoffmann, T., and Borrmann, S.: Characterization of the South Atlantic marine boundary layer aerosol using an aerodyne aerosol mass spectrometer, Atmos. Chem. Phys., 8, 4711-4728, https://doi.org/10.5194/acp-8-47112008, 2008. 